\title{
A GLOBAL REVIEW OF NON-LIVING RESOURCES ON THE EXTENDED CONTINENTAL SHELF
}

\author{
Bramley J. Murton
}

Received October 11, 2001 / Accepted December 05, 2001

\begin{abstract}
This contribution reviews the current state of knowledge of non-living resource potentials within the extended "legal " continental shelf(ELCS). The ELCS lies beyond the 200 nautical mile jurisdiction of nation states' exclusive economic zones, but within the outer limits defined by the criteria established under the 1982 United Nations Convention on the Law of the Sea, Article 76 (1982). The offshore non-living resource potentials are based on a statistical evaluation of known occurrences and reserves, the geologic environments favourable for their formation, models for sediment type and thickness, and basement composition. The result is an assessment of the potential for non-living marine resources to occur. The resources are divided into different types, based on their origin. Each is treated separately with a brief description of modes of formation followed by location, grade and resource estimate. Because placer deposits, comprising heavy minerals, gold and diamonds, are limited to near-shore areas they have negligible resource potential in the ELCS regions. Similarly, because phosphorite occurs mainly in the equatorial oceans between $400 \mathrm{~m}$ and $1,500 \mathrm{~m}$ depth, they too have limited resource potential in ELCS areas. Evaporite deposits occur on many continental margins. However, they only occur within ELCS regions off eastern North America and western central Africa, where their resource potential is low. Polymetallic sulphides (PMS) are formed at volcanically active plate boundaries. With the exception of parts of the west Pacific and off the western coast of North America, where volcanically active plate boundaries are close to the continental margin, PMS resources are low in the ELCS regions. The major resource potential within the ELCS regions is held in iron-manganese nodules and crusts, oil, gas and gas hydrates. Four elemental metals are the main components of value in manganese nodules and crusts: manganese, copper, nickel and cobalt. Extrapolating known occurrences world wide, the total amount of these nodules and crusts within the ELCS regions may be as much as thirteen billion tonnes. Conventional oil and gas comprise an estimated 106 b.b.o.e. (billion barrels of oil equivalent) with a similar estimate of 115 b.b.o.e. for gas hydrates. In total, the resource potential (excluding recovery and production costs) contained within the ELCS regions of the world amounts to an estimated US\$11,934 trillions (at today's raw commodity prices).
\end{abstract}

Key words: Extended "legal “" continental shelf; Marine Minerals Resources.

VISÃO GLOBAL DOS RECURSOS MINERAIS NÃO RENOVÁVEIS DA PLATAFORMA CONTINENTAL - Este trabalho examina o estado do conhecimento dos recursos minerais potenciais não renováveis dentro da Plataforma Continental Jurídica (Extended "Legal" Continental Shelf-ELCS). A ELCS localiza-se para além das 200 milhas náuticas sob jurisdição dos respectivos estados-nações. Os recursos potenciais não renováveis da ELCS são baseados numa avaliação estatística das ocorrências conhecidas e reservas, nos ambientes geológicos favoráveis a sua formação, em modelos para o tipo e espessura dos sedimentos existentes e na composição do substrato. Os recursos podem ser classificados em diferentes tipos, de acordo com a sua origem. Os depósitos de placers, constituídos por minerais pesados, ouro e diamantes, estão limitados as áreas costeiras. Estes constituem recursos praticamente negligiveis nas ELCS. As fosforitas ocorrem principalmente nos oceanos equatoriais a profundidades compreendidas entre os 400 e $1500 \mathrm{~m}$, estes constituem, igualmente, recursos limitados nas ELCS. Os depósitos evaporíticos ocorrem em muitas margens continentais; contudo, eles encontram-se somente no interior das ELCS localizadas na parte Leste da América do Norte e no Oeste da África Central. Os sulfetos polimetálicos são formados nos limites de placas com vulcanismo ativo. Com exceção das 
regiões do Pacifico Oeste e da Costa Oeste da América do Norte, onde os limites de placas estão muito próximos das margens continentais, estes recursos são relativamente baixos nas ELCS. Estão entre os recursos de maior potencial no interior das ELCS, os nódulos e crostas de ferromanganês, petróleo, gás e hidratos de gás. Os principais componentes de valor nos nódulos e crostas de manganês são quatro metais: cobre, níquel, cobalto e manganês. Fazendo uma extrapolação das ocorrências mundiais conhecidas, a QUANTidade total dos nódulos e crostas no interior das ELCS pode atingir as TREZE bilhões de toneladas. Uma estimativa para o petróleo e gás convencionais situa-se nos 106 B.B.O.E. (billion barrels of oil equivalent-equivalente em bilhões de barris de petróleo); valor semelhante é obtido para a estimativa dos hidratos de gás - 115 B.B.O.E. No total, os recursos potenciais (excluindo-se os custos de recuperação e de produção) contidos nas ELCS do nosso planeta atingem uma estimativa de 11,934 trilhões de dólares americanos (aos preços a que estas matérias primas são hoje comercializadas)

Palavras-chave: Plataforma Continental Jurídica; Recursos Minerais Marinhos.

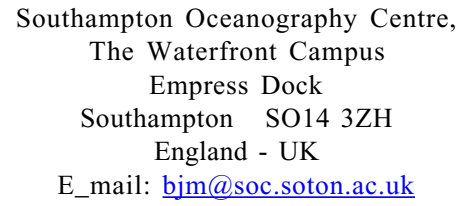

\section{INTRODUCTION}

The non-living resources of the deep ocean floor are increasingly being turned to as an alternative to land-based resources. For example, offshore oil and gas reserves now constitute a major portion of overall energy sources (IEA, 1996). As other non-living resources become scarce on land, or offshore exploitation becomes increasingly feasible through technological advances, more minerals can be expected to be mined from the offshore areas. Many of these resources are usually found on the continental shelf and its extensions and therefore give to the adjacent coastal state a potential for control over their exploitation. It is now the responsibility of the International Seabed Authority (ISA) to identify the potential for marine resources in areas beyond the control of coastal states and manage how these can be enjoyed for the benefit of humanity as a whole.

This contribution forms a review of non-living marine resources on the extended "legal " continental shelf (ELCS). The review examines non-living resources held by offshore minerals in areas that lie beyond the 200 nautical mile jurisdiction of nation states' exclusive economic zone (EEZ) but which have the potential to lie within their ELCS. The outer limits to these are defined by the criteria established by the United Nations Convention on the Law of the Sea, Article 76 (1982) and are based on bathymetry, sediment thickness and an assessment of geological continuity from the adjacent land masses.

The main mineral deposits of potential economic value that occur on and beneath the seafloor in the extended continental shelf areas are: placer deposit, phosphorites, evaporites, polymetallic sulphides (PMS), manganese-cobalt rich nodules and crusts and hydrocarbons including gas hydrates (Kesler, 1994; Cronan, 1980, 1985). Substantial mineral deposits are now known or predicted to occur on the seafloor in many parts of the world (Gross \& McLeod, 1987; Herzig, 1999, Herzig \& Hannington, 2000). However, there are significant differences dependent on platetectonic location, geological history, basement structure and sediment supply (Kesler, 1994).

\section{METHODOLOGY}

The offshore non-living resource potentials described here are based on a statistical evaluation of known occurrences and reserves, the geologic environments favourable for their formation, models for sediment type and thickness, and basement composition. Data for this report are compiled from published literature, manuscripts, atlases, charts, CDROMs and core texts on marine resources, as well as the databases of the British Oceanographic Data Centre (BODC), the US' National Geophysics Data Centre (NGDC), GeoRef, Geobase, Engineering 
Virtual Library (EEVL), Marine Oceanographic and Freshwater Resources (MOFR), the UK's Ocean Information System (OCEANIS), Ocean Treaties, and other online databases. These resources are utilised alongside databases of world bathymetry (e.g. GEBCO), sedimentology and geophysics to enable a comprehensive and quantitative synthesis of the offshore, non-living resource potential.

\section{Determination of the area of interest}

A critical parameter in the determination of marine resources in the area of the legally extended continental shelf is the definition of the area itself. Article 76 of the United Nations Law of the Sea Convention (1982) provides the definition and criteria for the location of the outer limit of the Legal Continental Shelf beyond 200 nautical miles. These are based on a combination of geodetic, geophysical, geological and hydrographic parameters and are published by the Commission for the Outer Limit of the Continental Shelf at http:// www.un.org/Depts/los/tempclcs/docs/clcs/ CLCS_11.htm.

Using these criteria, a number of authors have made attempts to identify the areas of the worlds oceans which, as legal Continental Shelf, fall beyond 200 nautical miles from the baselines from which territorial limits have been determined. One of the most widely cited is Prescott (1985) and is used here as a guide to locating the extended legal continental shelf regions.

\section{Classification of mineral resources}

To give economic and geologic perspectives to estimates of resource potentials, they must be examined within a framework that accounts for the degree of uncertainty of knowledge about their existence, formation, character and feasibility of recovery (Pearson, 1975; Kesler, 1994). In the original classification of McKelvey (1968) and McKelvey \& Wang (1969), individual mineral deposits evolve from being an estimated "resource" to a known "reserve" with progress in exploration, advance in technology, and changes in economic conditions. Recoverable "reserves" comprise known abundance and volume of materials that are both marketable and economically feasible to produce under local economic and technologic conditions. In contrast, "resources" comprise estimates of the potential occurrence and abundance of materials, regardless of their feasible exploitation. Our use here of the term "resource" is within the context of the definition supplied by McKelvey \& Wang (1969). Seen in this framework, the presently recoverable proven "reserves" of most minerals are relatively small when compared with the estimated "resources" that may be found by future exploration, or become economically recoverable as a result of technological advances. This is particularly true for marine resources, because only a small part of the seabed has been explored and most of the resources it contains are not yet economically recoverable (Li, 1995).

\section{Methods used to assess resource potentials}

We use four stages to assess the distribution and abundance of non-living resources on ELCS. For some resources, not all stages are possible, and in these cases we progress the evaluation as far as reasonable, or possible, to reach a qualitative ranking of resources by region.

The first stage involves identification of all documented occurrences of resource minerals in the global ocean. These occurrences include coastal, continental shelf, continental slope, continental rise and abyssal locations, regardless of their relationship to the ELCS. The second stage is to determine the resource density in mass per unit area for the various minerals and elements. For example, the distribution and density of manganese nodules and crusts are based on reports in the literature of seabed surface coverage determined from sampling and photographic observations. For conventional hydrocarbons (gas and oil), existing regions of production are identified, as well as reserves and resources estimated from regional compilations. Where appropriate, a third stage is to assess chemical compositional data for elements of significant economic value. These are largely restricted to manganese nodules and crusts, for which there is global data coverage. The forth stage continues the evaluation by multiplying the occurrence, frequency or density of resource minerals (in mass per unit area) with elemental abundance data for those minerals to 
arrive at estimates of mass per unit area for individual elements. These values are integrated under the area of the ELCS to derive the total elemental mass in each region. Where this is not possible to define quantitatively, the resources are ranked in order of potential abundance or grade.

Where global data for both abundance and composition exist, these are compiled on $1^{\circ}$ latitude and longitude grids. Interpolation of data between sampled localities is based on a minimum surface tension routine (Smith \& Wessel, 1990). This method has the advantage of adjusting value gradients locally according to the actual sample values, their location and frequency of occurrence. Because interpolation is not believed to give meaningful results beyond a limit of $10^{\circ}$ in both latitude and longitude from known occurrences, the grids do not extended beyond those limits.

Where abundance, density and compositional data are absent, the likelihood of occurrence of a specific resource is estimated from knowledge of the presence or absence of conditions favourable for the resource's formation. This method is especially applicable to gas hydrates and conventional hydrocarbons, although the latter are also assessed with reference to known reserves and estimated resources.

\section{NON-LIVING RESOURCES ON THE SEAFLOOR: THEIR FORMATION, OCCURRENCE AND MAGNITUDE}

\section{Marine Placer deposits}

Marine placers deposits are concentrations of detrital heavy metallic minerals that have become separated from their normal assemblage of lighter minerals. Harben \& Bates (1990) identify the most economically important of these minerals (and their associated elements) as: cassiterite (tin), ilmenite (titanium), rutile (titanium), zircon (zirconium), chromite (chromium), monazite (thorium), magnetite (iron), gold and diamonds.

Placer deposits are formed in high-energy environments such as the surf-zone along beaches. As a result of their specific high density, placer minerals are generally confined to locations within a few tens of kilometres from their source rocks. The relationship between sea-level changes and the formation and preservation of placer deposits puts limits on their occurrence offshore. During the last glacial maximum (18,000 years ago), when sea level was lowered by $\sim 120 \mathrm{~m}$, fluviatile placer deposits may have extended to the edge of the present-day continental shelf (Kudrass, 1987, 2000). However, with subsequent sea level rise, many of these deposits were buried by sediment transgression.

In general, two different types of marine placer deposits are recognised (Emery \& Noakes, 1968; Kudrass, 1987, 2000; Jury \& Hancock, 1989). Fluviatile placer deposits of gold and cassiterite that originated on the inner shelf during periods of falling sea level and beach placers that originated during periods of stable or slightly fluctuating sea-level. However, most placer deposits along present shorelines are largely the result of transgressive beachbarrier migration. This is a mechanism by which much of the shelf sand, with its pre-concentrated heavymineral assemblages, was moved to its present coastal position during transition from glacial to interglacial periods. Although a few shelf deposits were large enough to survive the transgression process, they are usually disseminated and of low grade and hence of little economic value (Komer \& Wang, 1984).

As a result of their higher density $(>3.2 \mathrm{gcm}-3)$ compared to the bulk of detrital minerals, which consist mostly of quartz and feldspar (with a density of 2.7 $\mathrm{gcm}-3)$, most placer deposits are formed close to their source rocks. These are mainly continental rocks of volcanic, plutonic, or metamorphic origin and cover a broad compositional range. The distribution of presently known placer deposits of economic significance lie mainly on the shallow shelf, within EEZs and none are located beyond 200 nautical miles within the areas of the ELCS (Emery \& Noakes, 1968; Shilo, 1970; Jones \& Davies, 1979; Cronan, 1980, 1983; Earney, 1990; Kudrass, 2000; Yim, 1991, 2000).

Rutile and ilmenite have been mined from placerderived deposits from beach sand in south-east and south-west Australia, in east South Africa, south India, Mozambique, Senegal, Brazil, and Florida. The irontitanium-rich placer mineral magnetite has been mined 
in large quantities from the northwestern coast of New Zealand (North Island), Indonesia (Java), the Philippines (Luzon), and Japan (Hokkaido). Cassiterite, occurring in fluviatile placers, is recovered from near-shore and offshore sediments in the "tinvalleys" of the Indonesian Sunda shelf(extending from the islands of Bangka, Belitung, and Kundur), Malaysia, and Thailand, where about one third of the world's production is derived. The majority of presently recovered gold is derived from fluviatile placer deposits although it sometimes occurs in beach placers (e.g. in New Zealand and Alaska). Placer diamonds are mainly mined in beach and shelf sediments along the west coast of South Africa and Namibia.

Because marine placer deposits are generally confined to locations within a few tens of kilometres from their source rocks, and are related to Pleistocene sea-level changes, they are limited to continental shelf regions less than $120 \mathrm{~m}$ deep. Therefore, although lying within coastal states' EEZ, it is unlikely for placer deposits to occur as resources on the ELCS which is beyond 200 nautical miles from the coast and generally at a depth greater than $100 \mathrm{~m}$.

\section{Marine phosphorite deposits}

Phosphorites are natural compounds containing phosphate in the form of a cement binding sediments in tropical to sub-tropical regions. They tend to occur in waters of medium depth and are widely distributed on the continental shelves and upper slopes in areas of deep-water upwelling. They also occur on oceanic islands, seamounts and the flanks of atolls (Burnett \& Riggs, 1990). Phosphorite consisting of varieties of the heavy mineral apatite is also formed authigenically in some sediments (Manheim, 1979; Cruikshank, 1992; Bentor, 1980).

Present-day locations of phosphorite deposits are shown on Figure 1. Relatively rich deposits are known to occur in areas such as off the coast of Baja California, southern California, and east of New Zealand. However, in many places they consist of cemented nodules scattered within sediment, and are too sparsely distributed to be recoverable. The phosphate content of known deposits varies considerably and is seldom more than 29 wt. \% (Baturin \& Savenko, 1985; Baturin 1998; Rao \& Nair, 1991).



Figure 1. Location of known marine phosphorite deposits (in light black - after Baturin and Savenko, 1985; Baturin 1998; Rao and Nair, 1991; Earney, 1990) and evaporite deposits (in dark grey - after Cronan, 1980; Earney, 1990; Warren, 1999; Teleki et al., 1987 and others cited in the text) with reference to the ELCS regions (in pale grey) and EEZ areas (outlined by thin curved grey lines) - modified after Prescott, 1985. 
The large, commercially valuable deposits of Nauru, Ocean and Christmas Islands are well known and there is the potential for similar deposits to occur on shallow (less than $120 \mathrm{~m}$ deep) submerged seamounts within the Pacific region that were above sea level prior to the last sea level rise (Bentor, 1980). There are also potential, low grade phosphorite deposits on the Chatham Rise off New Zealand, (with $\sim 5$ wt. \% phosphate) and offshore from Cochin and Bombay, India. Other major localities include the shelf off south and south-western Africa, north-western Africa, the western and eastern margins of South America and western Australia (Cruikshank, 1992; Manheim, 1979). However, few of these locations overlap with the ELCS, except for a small part of the south-eastern margin of Argentina.

World marine resources of phosphorite are probably at least of the order of hundreds of billions of tonnes (Kent, 1980; Pearson, 1975; Manheim, 1979). As a consequence of prevailing economic conditions and the alternative availability of phosphates from non-marine sources, no offshore deposits are being mined at present. Although land deposits are large enough to meet world demands, marine production may become economically viable in local areas far removed from on-shore deposits. Of these, possibly a few billion tons of offshore deposits may become economically viable (e.g. those associated with already identified major deposits). However, the bulk of marine phosphorite resources in the ELCS are unlikely to become economic viable and are hence of little economic value.

\section{Marine evaporite deposits}

Marine evaporites, formed by evaporation of sea water and other natural brines in geologic basins of restricted circulation, comprise mainly anhydrite and gypsum (calcium sulphates), sodium and magnesium salts and potash-bearing minerals (Holser, 1979; Peryt, 1987; Holser et al., 1988). Elemental sulphur, although not strictly an evaporite, forms in association with some deposits by biogenic alteration of anhydrite. Because rock salt tends to flow at relatively low temperature and pressure, thick salt strata is often remobilised by the weight of the sedimentary overburden causing upward protrusion forming salt domes, plugs, and other diapiric structures. Such masses, which can be a few kilometres in diameter, may bring salt to or near the surface. They can also form structures in the intruded sedimentary strata that are favourable for the accumulation of hydrocarbons.

Figure 1 shows the present day occurrence of marine anhydrite, potash and magnesium evaporite deposits. Although evaporite deposits formed in ancient marine basins are extensive on land, many of these also extend beneath the sea, not only under the continental shelves but also under some marginal ocean basins. Examples of these include the Sigsbee Deep salt domes in the Gulf of Mexico, the Canadian Arctic (including Hudson Bay), the north-west African shelf, the Mediterranean Sea, north-eastern margin of Brazil, the Grand Banks and Newfoundland, parts of eastern African margin and western Australia (Warren, 1999; Teleki et al., 1987). Although falling within the range of EEZ, very few of these known areas of anhydrite, potash and magnesium evaporite deposits extend into the ELCS. Possible exceptions to this may be the Grand Banks and Newfoundland deposits, west Africa and north-western Australian deposits. However, very little data exist on the abundance or concentration of these deposits.

Because of the widespread occurrence of anhydrite, gypsum and common salt on land, and the ease of obtaining salt by evaporation from seawater in many coastal regions, these minerals are already widely available. Consequently, there is little value in marine deposits except perhaps in areas far removed from other supplies. To our knowledge, no attempt has been reported to quantitatively estimate potential marine resources of evaporitic salt and anhydrite deposits, but they probably amount to at least tens of trillions of tonnes (Warren, 1999). Potash deposits in evaporite basins are not as widespread as salt and gypsum, but individual deposits are generally in the range of hundreds of millions to billions of tonnes. Potash resources in marine deposits are probably in the range of tens of billions of tonnes, some of which maybe economically recoverable. Thick beds of a magnesium salt and tachydrite (calcium-magnesium hydrate), previously known only in trace concentrations, occur in areas associated with potash deposits in the Sergipe salt basin along the eastern coast of Brazil and in the Congo basin along the mid- 
southwestern coast of Africa.

\section{Marine Polymetallic sulphides}

The majority of sub-sea polymetallic sulphides (PMS) are massive ore bodies containing varying proportions of pyrrhotite, pyrite/marcasite, sphalerite/ wurtzite, chalcopyrite, bornite, and isocubanite. Some massive polymetallic sulphides located on spreading centres near deep-ocean trenches also contain galena (lead sulphide) and native gold. Other minor sulphides of tin, cadmium, antimony, aresenic and mercury also occur in varying amounts at different localities (Rona \& Koski, 1985; Herzig \& Hannington, 1995).

Polymetallic mineral deposits on the seafloor are intimately related to the formation of new oceanic crust by seafloor spreading and volcanic activity. At midocean ridges, convection-driven hydrothermal circulation of seawater through young oceanic crust is the principal ore-forming process (Scott, 1985; Herzig \& Hannington, 1995). Hydrothermal fluids leach and transport metals and other elements at depth from their volcanic host rock to the surface of the seafloor. As they discharge, at temperatures up to $350^{\circ} \mathrm{C}$ from "black smoker" chimneys (at depths in excess of 2,500 m), metal sulphide deposits form at the seafloor (as mounds) or as sub-surface stockworks. Lower temperature systems are also present and generate mineralisation of considerable economic potential. In the southern Lau Basin, for example, the first examples of actively forming, visible primary gold in seafloor sulphides were documented at "white smoker" chimneys from fluid discharge at $150-200^{\circ} \mathrm{C}$ (Hannington, \& Scott, 1988; Herzig et al., 1993).

Submarine massive polymetallic sulphide bodies are principally found along the earth's major tectonic boundaries. The main areas of occurrence are fast-, intermediate-, and slow-spreading mid-ocean ridges, on- and off-ridge volcanoes and seamounts, in sedimented rifts adjacent to continental margins and in volcanoes and spreading ridges asssociated with deep-ocean trenches (Rona, 1988; Rona \& Koski, 1985; Herzig, 1999; Herzig \& Hannington, 2000). High-temperature hydrothermal activity and large accumulations of polymetallic sulphides are located from at least 25 different sites world wide (Fig. 2).

Plate tectonic setting has an important influence on the composition of PMS deposits. For example, back-arc basins related to subduction zones are important sites for base-metal and gold mineralisation. In the southwestern Pacific, the "PACMANUS"

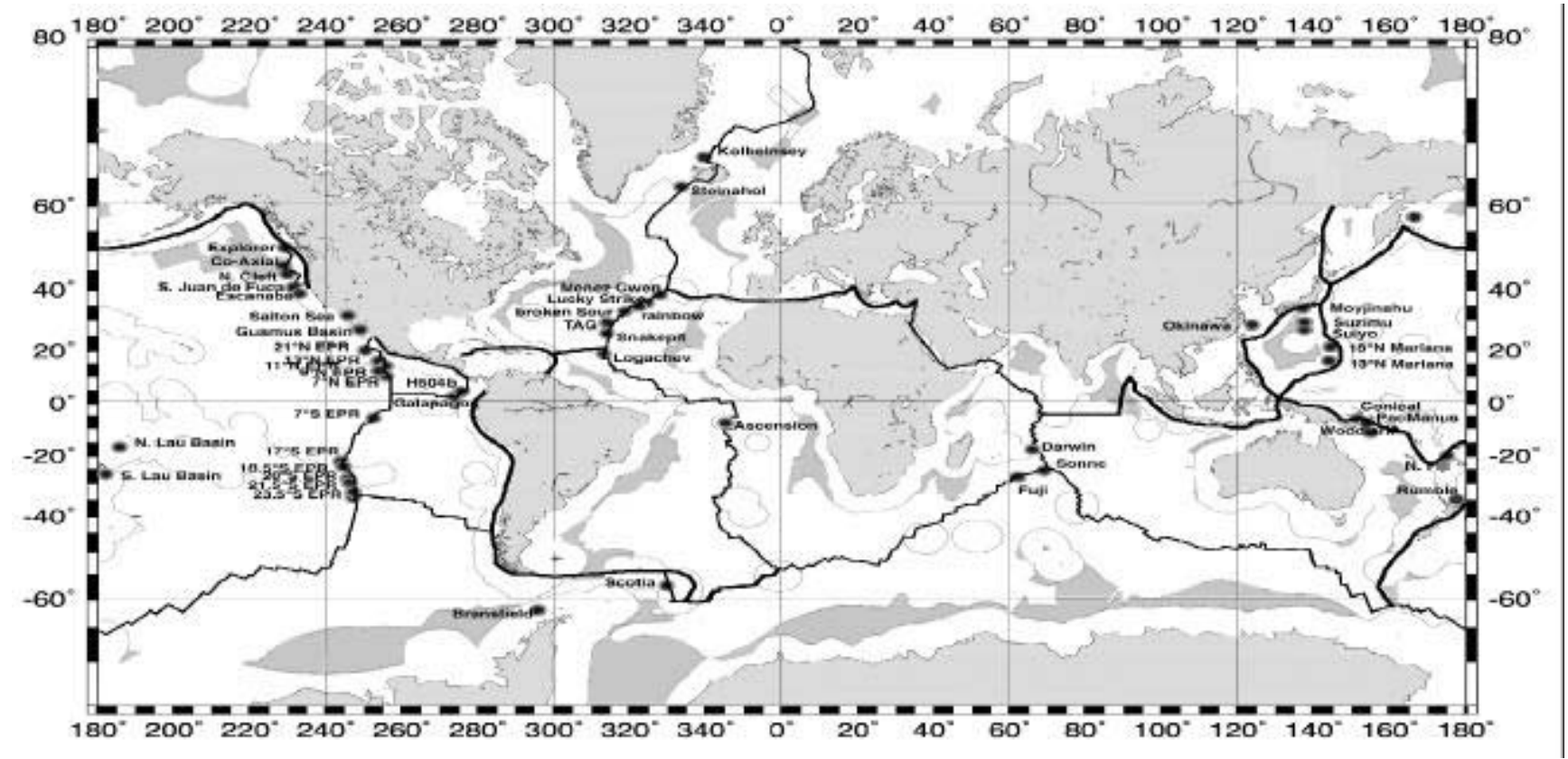

Figure 2. Location of known marine polymetallic sulphide (PMS) deposits and active hydrothermal system (grey-filled circles modified after: Rona, 1988; Rona \& Koski, 1985; Herzig, 1999; Herzig \& Hannington, 2000 and others cited in the text) with reference to the ELCS regions (in grey), EEZ areas (outlined by thin curved grey lines), and the major oceanic plate boundaries (in bold black lines). 
hydrothermal deposits are scattered along a $10 \mathrm{~km}-$ long crest or section of an active volcanic ridge in the eastern Manus Basin, Papua New Guinea. Here, chimneys dominated by chalcopyrite and sphalerite, with barite and some bornite, have average compositions of $11 \mathrm{wt} \% \mathrm{Cu}, 27 \% \mathrm{Zn}, 230 \mathrm{ppm} \mathrm{Ag}$ and $18 \mathrm{ppm} \mathrm{Au}$ (Moss et al., 1997; Scott and Binns, 1995; Binns et al.2 1993). The shallow depths (less than $1,500 \mathrm{~m}$ ) and high gold content make such sites potentially viable for mining.

Very little is known about the total metal content of marine PMS deposits and their sub-surface extent. Because of their depth (greater than 2,500 m) and remote locations from shore, it is unlikely that seafloor PMS deposits, such as those located in international waters on the mid-ocean ridges (e.g. the Mid-Atlantic Ridge, East, Northeast and Southeast Pacific Rises, and the Indian Ocean ridges), will become mining targets in the forseeable future (Agterberg \&Franklin, 1987). However, massive sulphide mining may have some economic viability in the near future where there are high gold and base-metal grades at sites that are located close to land and in water depths less than 2,000 m (Broadus, 1985).

Figure 2 shows the locations of known hydrothermal activity, PMS deposits and their geologic setting, and can be used to identify those areas where conditions for recovery may become viable. Those with the greatest potential are located in: the southwest Pacific, the Scotia Sea, the Guyamus Basin (Gulf of California), northern East Pacific Rise, and possibly parts of the Juan de Fuca Ridge of western North America. Although none of these areas currently lie within any potential ELCS, even for those that are already known, the logistical difficulty for their recovery make them all currently uneconomic. The only exception to this is possibly the PACMANUS deposit in the eastern Manus Basin (Bismarck Sea, north of Papua New Guinea), for which the Papua New Guinea authorities recently granted two exploration and development licences to the Nautilus Mineral Corporation in 1999.

\section{Marine manganese nodules and crusts}

Traditionally, manganese nodules have provided a source for much speculation about economically viable mineral resources in the deep ocean. Their abundance, composition, (including strategically valuable metals) and their occurrence as loose material lying on the surface of the seabed make nodules potentially attractive to future mining. Manganese nodules were first dredged during the HMS Challenger Expedition in the Pacific Ocean in 187276 (Murray, 1878; Murray \& Irvine, 1895; Murray $\&$ Renard, 1891). The currently known distribution of manganese nodules and crusts on the ocean floor is based on information acquired by sidescan sonar, drill cores, dredged samples, seafloor photos, video camera records and direct observation from submersibles. A recent review of nodule and crust locations, their compositions and abundance, has been compiled by the USGS, NOAA and US Mineral Management Service (1991), Rawson \& Ryan (1978) and others (see text for specific references). These data form the basis of the analysis of this resource assessed here.

Manganese nodules are concentrations of iron and manganese oxides, that can contain economically valuable concentrations of nickel, copper and cobalt (together, making up to $3 \mathrm{wt}$ \%). They range from millimetres to tens of centimetres in diameter and occur mainly on the deep-seafloor. Apart from manganese and iron oxide, nickel, copper and cobalt, the nodules include trace amounts of molybdenum, platinum and other base metals (Cronan, 1980; Manheim, 1986). Additionally, manganese rich crusts, similar in composition to the nodules, occur on rocky outcrops and in places on unconsolidated clastic sediments. The thickness of these crusts ranges from $2 \mathrm{~cm}$ in the upper slope areas to $9 \mathrm{~cm}$ in the lower areas where they may contain more than $16 \mathrm{kgm}-2$ (dry weight) of encrusted surfaces (Halbach \& Manheim, 1984. They are most common on old seamounts and the submerged flanks of ocean islands where they can be enriched by up to two per cent in cobalt (Halbach et al., 1983, Halbach, 1989; Mero, 1965; Glasby, 1977).

The major mineral phases of iron and manganese oxides control the uptake and retention in the nodules of minor elements such as nickel, copper, cobalt, molybdenum and rare earth elements (Cronan, 1977). Of the large number of complex hydrous manganese oxide mineral phases identified, todorokite and 


\begin{tabular}{|llll|}
\hline $\begin{array}{l}\text { Average elemental } \\
\text { content (dry wt. \%) }\end{array}$ & Atlantic & Pacific & Indian \\
Manganese & 15.46 & 19.27 & \\
Iron & 23.01 & 1179 & 15.25 \\
Nickel & 0.308 & 0.846 & 13.35 \\
Copper & 0.141 & 0.706 & 0.534 \\
Cobalt & 0.23410 & 0290 & 0.295 \\
Manganese/Iron & 0.67 & 1.6 & 0.247 \\
\hline
\end{tabular}

Table 1 - Average elemental concentrations for manganese nodules from different seafloor provinces (after: Cronan, 1977, 1980, 2000; Gross \& McLeod, 1987).

birnessite are the most common. In addition, nodules and crusts contain a variety of non-metallic minerals, amorphous material and biological debris that may comprise up to $25 \mathrm{wt}$ \% of their dry mass (Gross \& McLeod, 1987). These include clay minerals, quartz, feldspar and chlorite, mostly of detrital origin along with varied proportions of silica gels, chalcedony, calcareous and phosphatic components. The ratio of different mineral phases, and their relationship to different environments, has been documented by Burns \& Burns (1977), Hein et al. (1997), Hein \& Morgan (1999) and Mitchell \& Garson (1981).

Gross \& McLeod (1987) report that the major elements in dry nodules are oxygen, manganese, iron, silica, and lesser amounts of aluminium, calcium, sodium, and magnesium. Trace elements of greatest economic interest are nickel, copper, and cobalt (table 1). The amounts and proportions of constituents vary considerably within single nodules, between nodules of different sizes, and between nodules from different regions and ocean basins (Calvert, 1978; Hayes et $a l$, , 1985).
The composition of manganese crusts varies from 15 to $31 \mathrm{wt}$ \% manganese, 7 to $18 \mathrm{wt} \%$ iron, and with $\mathrm{Mn} / \mathrm{Fe}$ ratios ranging from 1.0 to 3.4. Although the cobalt content is generally higher for crusts than for nodules, with crusts containing up to $2 \mathrm{wt} \%$ cobalt occurring on the summits of some seamount of less than $1,500 \mathrm{~m}$ depth, the average cobalt content is 0.8 wt $\%$. Crusts can also contain significant amounts of nickel, lead, cerium, molybdenum, vanadium and other minor metals including those of the platinum group elements (Manheim, 1986).

The composition of manganese nodules and crusts also varies according to the different environment settings (table 2). Although nodules form at a rate of up to a few tens of millimetres per million years (Ku,1977; Cronan, 1980; Calvert, 1978), the most extensive nodule fields tend to occur on oceanic crust that is Mesozoic or younger in age. They are found mainly below the carbonate compensation depth in areas with low clastic sedimentation and with high biological productivity in overlying surface waters (Cronan, 1980, 2000).

\begin{tabular}{|llllllll|}
\hline & Seamounts & Plateaux & $\begin{array}{l}\text { Active } \\
\text { Ridges }\end{array}$ & $\begin{array}{l}\text { Other } \\
\text { Ridges }\end{array}$ & $\begin{array}{l}\text { Continental } \\
\text { Margins }\end{array}$ & $\begin{array}{l}\text { Marginal } \\
\text { Seamounts }\end{array}$ & $\begin{array}{l}\text { Abyssal } \\
\text { plains }\end{array}$ \\
$\mathrm{Mn}$ & 14.62 & 17.17 & 15.15 & 19.74 & 38.69 & 15.65 & 16.78 \\
$\mathrm{Fe}$ & 15.81 & 11.81 & 19.15 & 20.08 & 1.34 & 19.32 & 17.27 \\
$\mathrm{Ni}$ & 0.351 & 0.641 & 0.306 & 0.336 & 0.121 & 0.296 & 0.540 \\
$\mathrm{Co}$ & 1.15 & 0.347 & 0.400 & 0.570 & 0.011 & 0.419 & 0.256 \\
$\mathrm{Cu}$ & 0.058 & 0.087 & 0.081 & 0.052 & 0082 & 0.078 & 0.370 \\
$\mathrm{Mn} / \mathrm{Fe}$ & 0.92 & 1.53 & 0.80 & 0.98 & 28.8 & 0.81 & 0.97 \\
$\mathrm{Depth}$ & 1872 & 945 & 2870 & 1678 & 3547 & 1694 & 4460 \\
\hline
\end{tabular}

Table 2 - Average elemental abundance (in wt. \%) for $\mathrm{Mn}, \mathrm{Fe}, \mathrm{Ni}, \mathrm{Co}$ and $\mathrm{Cu}$ in manganese nodules and crusts from different seafloor settings and depths (in metres) (after Cronan, 1977). 
The metals contained in nodules and crusts are attributed to discharge of hydrothermal solutions along active plate boundaries, leaching of metals from the bottom sediments and volcanic rocks during diagenesis and the deposition of metal-rich clastic or colloidal sediment from continental erosion (Greenslate, et al. 1973; Glasby,1977; Eldersfield, 1977; Calvert,1978; Cronan, 1980).

Figure 3 shows the distribution and density of all known manganese nodules and crusts for which quantitative chemical analyses are reported and where estimates of their abundance have been mapped. These data have been compiled from sites where dredges, cores, submersibles and bottom photographs have been taken. Although the chemical analyses cover wide regions, the same is not true for estimates of the abundance of nodules and/or thickness of crusts. Therefore, the analyses presented here are only preliminary and should not be taken as anything other than a guide to this resource. Figures 4 to 7 show the abundance of the four elements that are of greatest economic importance in these deposits: manganese, copper, nickel and cobalt.

Cobalt is an especially important metal for which marine manganese nodules and crusts comprise a significant host. Important areas where cobalt-rich manganese crusts have been found in the Pacific include the north-west Hawaiian Ridge, Johnston Island, Huwlarid-Baker Islands, Marianas Island, Guam, Marshall Islands, Central Seamounts, PalmyraKingman, Micronesia and Wake Island (Manheim 1986). According to Clark et al., $(1984,1985)$ the area around the Federated States of Micronesia and the Marshall Islands also appears to have a much larger resource potential for cobalt, nickel, manganese and platinum than other island areas. Cobalt-rich manganese-iron crusts cover thousands of square kilometres in the Atlantic Ocean and are found on the Blake Plateau, Sierra Leone Rise, and the east flank of the Mid-Atlantic Ridge. Here crusts have cobalt contents of up to 1 wt. \%. Manheim (1986) reports a mean cobalt content of $0.5 \mathrm{wt}$. \% for 77 samples of crusts recovered from 2,500 $\mathrm{m}$ in the Atlantic Ocean and a range from 0.5 to $0.85 \mathrm{wt} . \%$, while the mean content of manganese is $20.15 \mathrm{wt}$. \% and ranges from 17.9 to 22.28 wt. $\%$. The average metal content in crust samples from the Hawaiian Archipelago and
Johnston-Palmyra Region in the Pacific is: $0.90 \mathrm{wt}$. $\%$ cobalt, 0.50 wt. $\%$ nickel, 0.06 wt. \% copper, and 24.7 wt. \% manganese, with an average thickness of 2.4 to $2.8 \mathrm{~cm}$ (Clark et al. 1984).

A region of special economic interest lies in the central north-east Pacific Ocean between the Clipperton and Clarion fracture zones (bounded by latitude $5^{\circ} \mathrm{N}$ and $25^{\circ} \mathrm{N}$ and longitude $270^{\circ} \mathrm{E}$ to $210^{\circ} \mathrm{E}$ - Morgan, 2000). Here, abundant nodules have a up to $30 \mathrm{wt}$. \% manganese, $1.5 \mathrm{wt} \%$ copper, 10,000 ppm cobalt and $2 \mathrm{wt} \%$ nickel. They have a combined content of nickel and copper of up to $3.5 \mathrm{wt} \%$. Nodules in this region are more concentrated than in most other areas, with averages up to $10 \mathrm{~kg} / \mathrm{m} 2$. However, nodule abundance varies considerably within local areas, and in isolated sites it ranges up to 30 kg/m2 (Hayes et al.,1985; Frazer, 1977). Our estimates of the elemental concentration on the seafloor in this region are up to $3 \mathrm{~kg} / \mathrm{m} 2$ for manganese, $80 \mathrm{gm} 2$ for copper, $25 \mathrm{mg} / \mathrm{m} 2$ for cobalt and $0.2 \mathrm{~kg} /$ $\mathrm{m} 2$ for nickel.

A large area in the Central Pacific Ocean (north of $28^{\circ} \mathrm{N}$ and between $180-200^{\circ} \mathrm{E}$ ) has widespread concentrations of nodules with average densities up to $10 \mathrm{~kg} / \mathrm{m} 2$ (Figure 3). These contain elemental concentration up to $20 \mathrm{wt}$. \% manganese, $1 \mathrm{wt}$ \% copper, $4000 \mathrm{ppm}$ cobalt and 1\% nickel, with combined nickel and copper concentrations of up to $2 \mathrm{wt}$. $\%$. The elemental density on the seafloor range up to $1.5 \mathrm{~kg} / \mathrm{m} 2$ for manganese, $60 \mathrm{~g} / \mathrm{m} 2$ for copper, $40 \mathrm{mg} / \mathrm{m} 2$ for cobalt and $0.75 \mathrm{~kg} / \mathrm{m} 2$ for nickel.

A number of locations, to the south-west of Hawaii (within an area $5^{\circ} \mathrm{N}$ to $10^{\circ} \mathrm{N}$ and $180^{\circ} \mathrm{E}$ to $195^{\circ} \mathrm{E}$ ), have concentrations of nodules and crusts averaging $2 \mathrm{~kg} / \mathrm{m} 2$. These contain elemental concentrations and densities on the seafloor of up to $10 \mathrm{wt}$. \% manganese at up to $1 \mathrm{~kg} / \mathrm{m} 2$, up to $1 \mathrm{wt} . \%$ copper at up to $10 \mathrm{~g} / \mathrm{m} 2$, up to $4000 \mathrm{ppm}$ cobalt with a maximum of $10 \mathrm{mg} / \mathrm{m} 2$, and $0.5 \mathrm{wt} . \%$ nickel with up to $0.025 \mathrm{~kg} / \mathrm{m} 2$. The combined nickel and copper concentration is up to $2 \mathrm{wt}$. $\%$.

Nodules densities of up to $8 \mathrm{~kg} / \mathrm{m} 2$ are found in the Pacific southern equatorial belt at the edge of the calcareous zone between $180^{\circ} \mathrm{E}$ and $220^{\circ} \mathrm{E}$. However, occurrences are infrequent throughout much of the area. An exception is an area between the East Pacific Rise and South America where we identify densities 


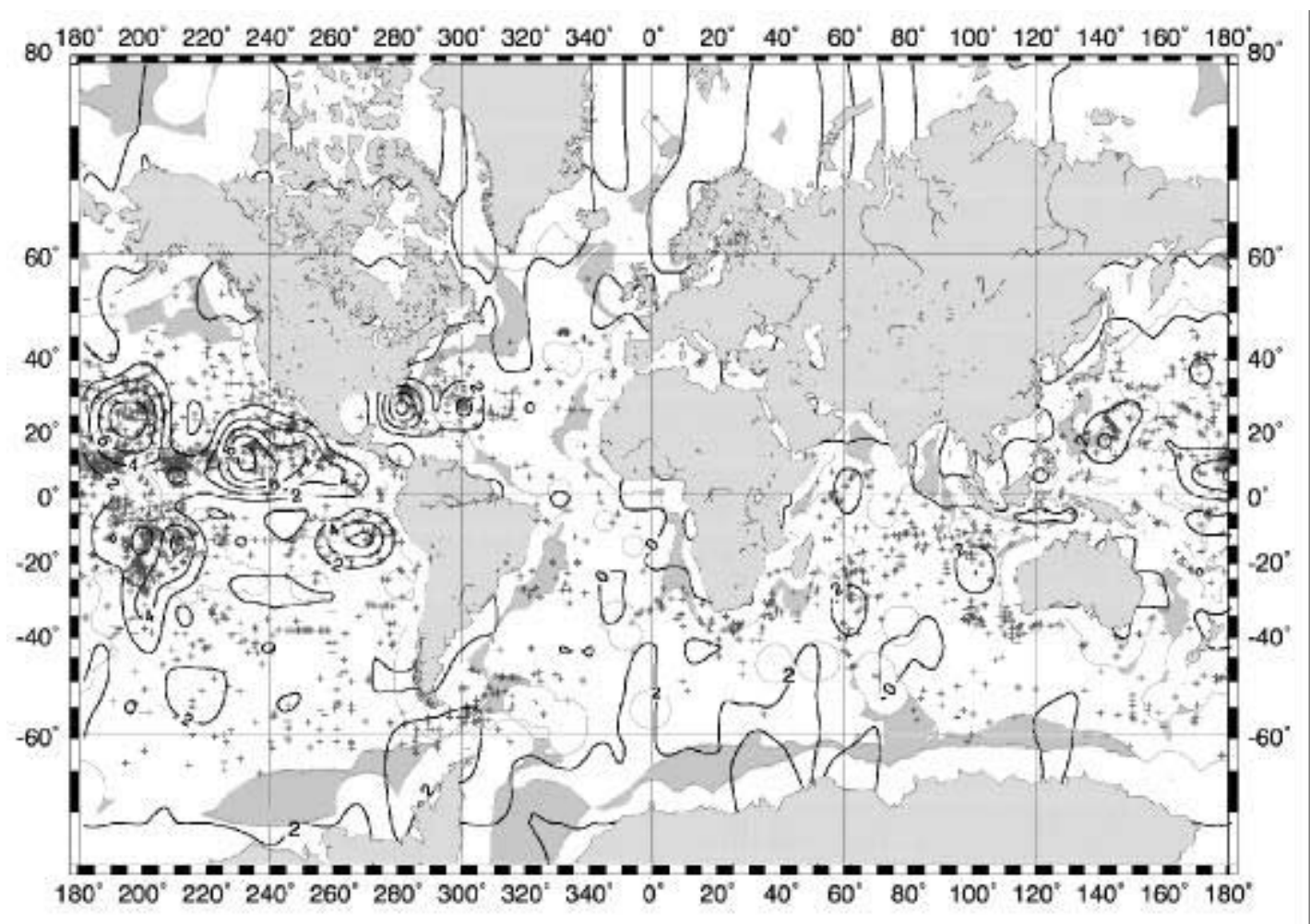

Figure 3 - Location of all reported marine manganese nodule and crust deposits (in crosses - after: NOAA \& MMS Marine Minerals CDROM Data Set, World Data Center for Marine Geology \& Geophysics, Boulder, 1991; Gross \& McLeod, 1987; Kesler, 1994, and other sources cited in the text) with reference to the ELCS regions (in grey) and EEZ areas (outlined by thin curved grey lines). Contours (black lines) are abundance of nodules and crusts on the seafloor in $\mathrm{kg} / \mathrm{m}^{2}$ and gridded on a $1^{\circ}$ latitude and longitude basis from data compiled from the sources cited.

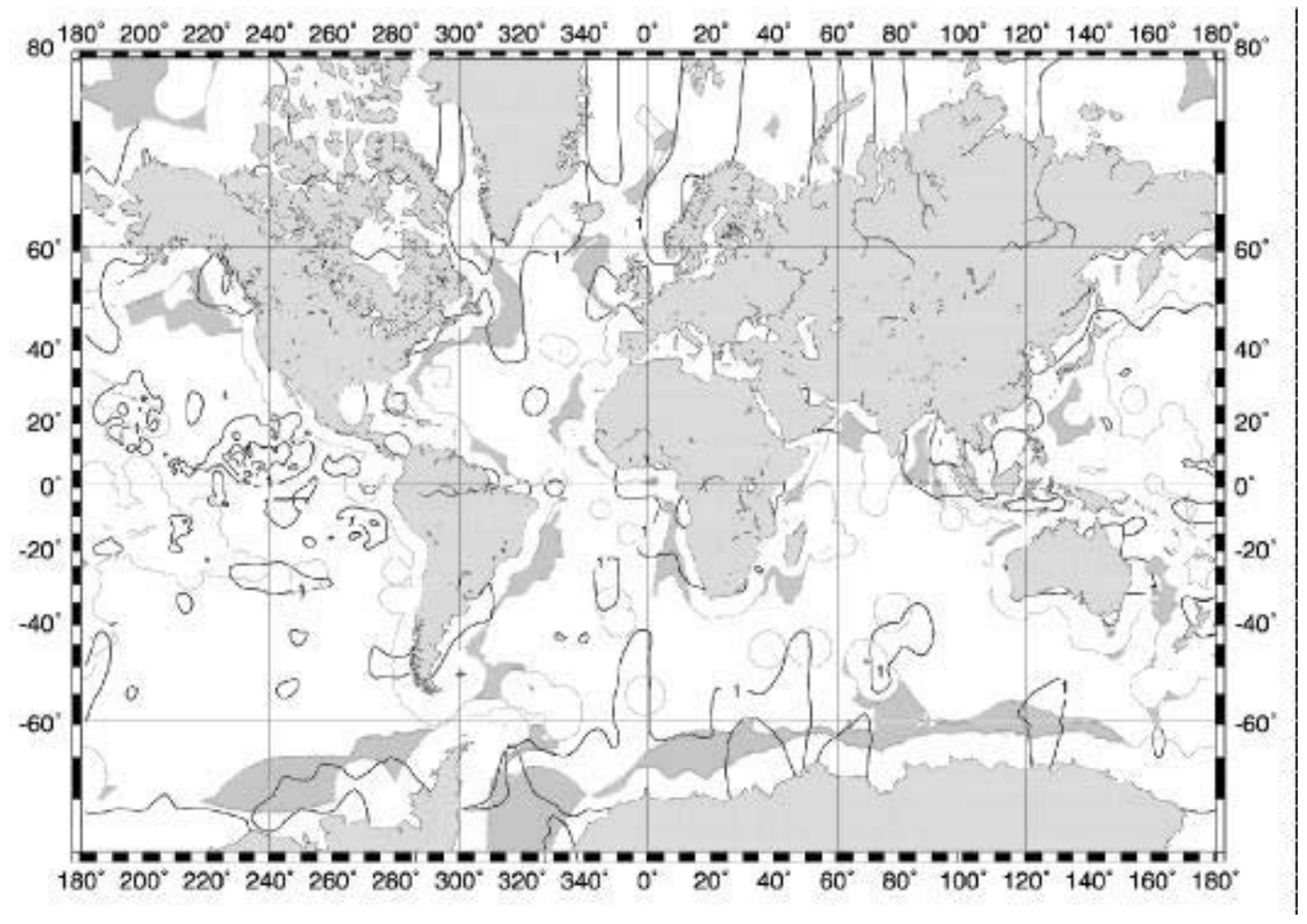

Figure 4 - Density of elemental manganese (contoured in $\mathrm{kg} / \mathrm{m}^{2}$ ) on the seafloor, contained in nodules and crusts, gridded on a $1^{\circ}$ latitude and longitude basis (from data compiled from the same sources cited on figure 3) and with reference to the ELCS regions (in grey) and EEZ areas (outlined by thin curved grey lines). 




Figure 5 - Density of elemental copper (contoured in $\mathrm{g} / \mathrm{m}^{2}$ ) on the seafloor, contained in nodules and crusts, gridded on a $1^{\circ}$ latitude and longitude basis (from data compiled from the same sources cited on figure 3) and with reference to the ELCS regions (in grey) and EEZ areas (outlined by thin curved grey lines).

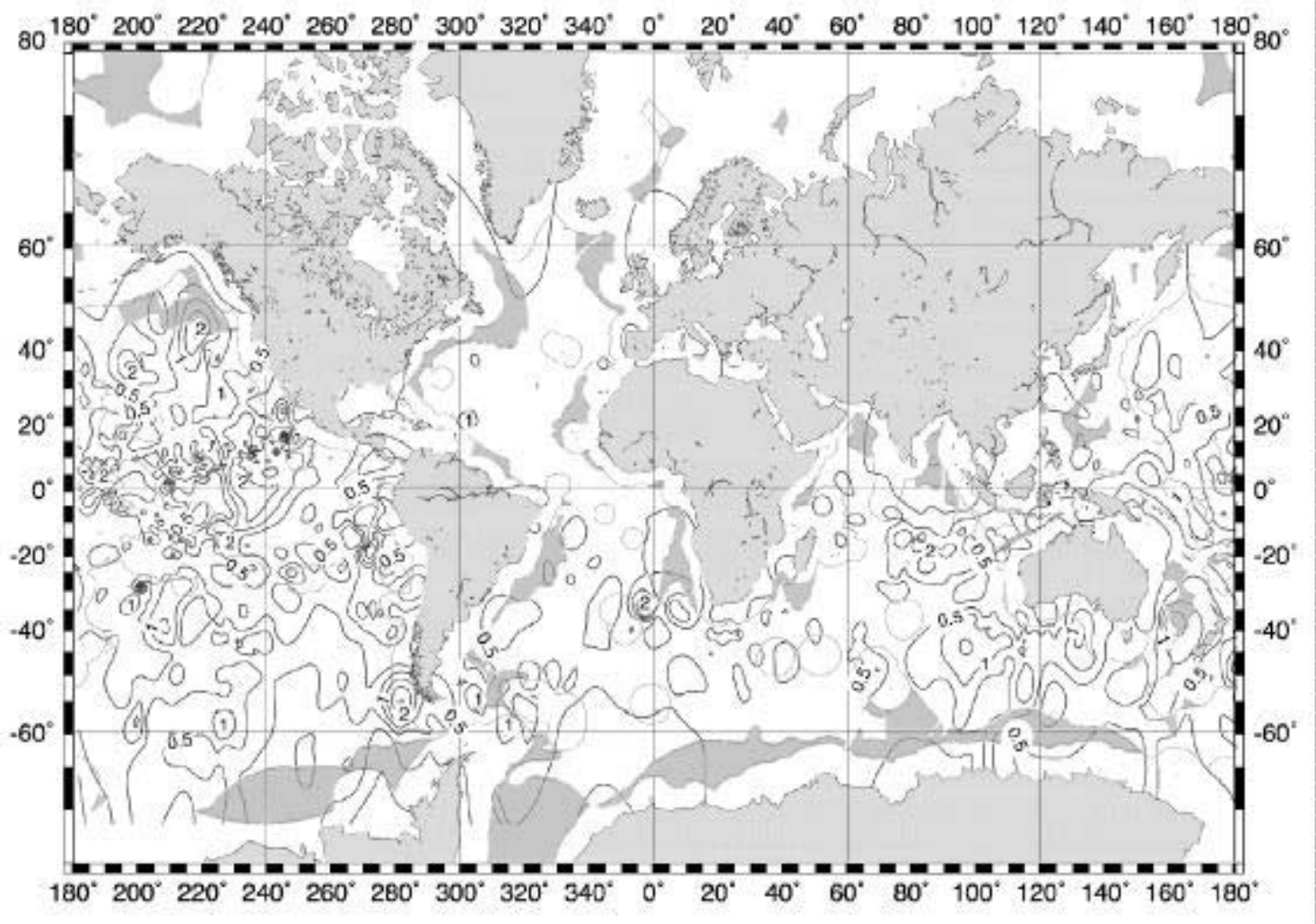

Figure 6 - Density of elemental nickel (in $\mathrm{kg} / \mathrm{m}^{2}$ ) on the seafloor, contained in nodules and crusts, gridded on a $1^{\circ}$ latitude and longitude basis (from data compiled from the same sources cited on figure 3) and with reference to the ELCS regions (in grey) and EEZ areas (outlined by thin curved grey lines). 


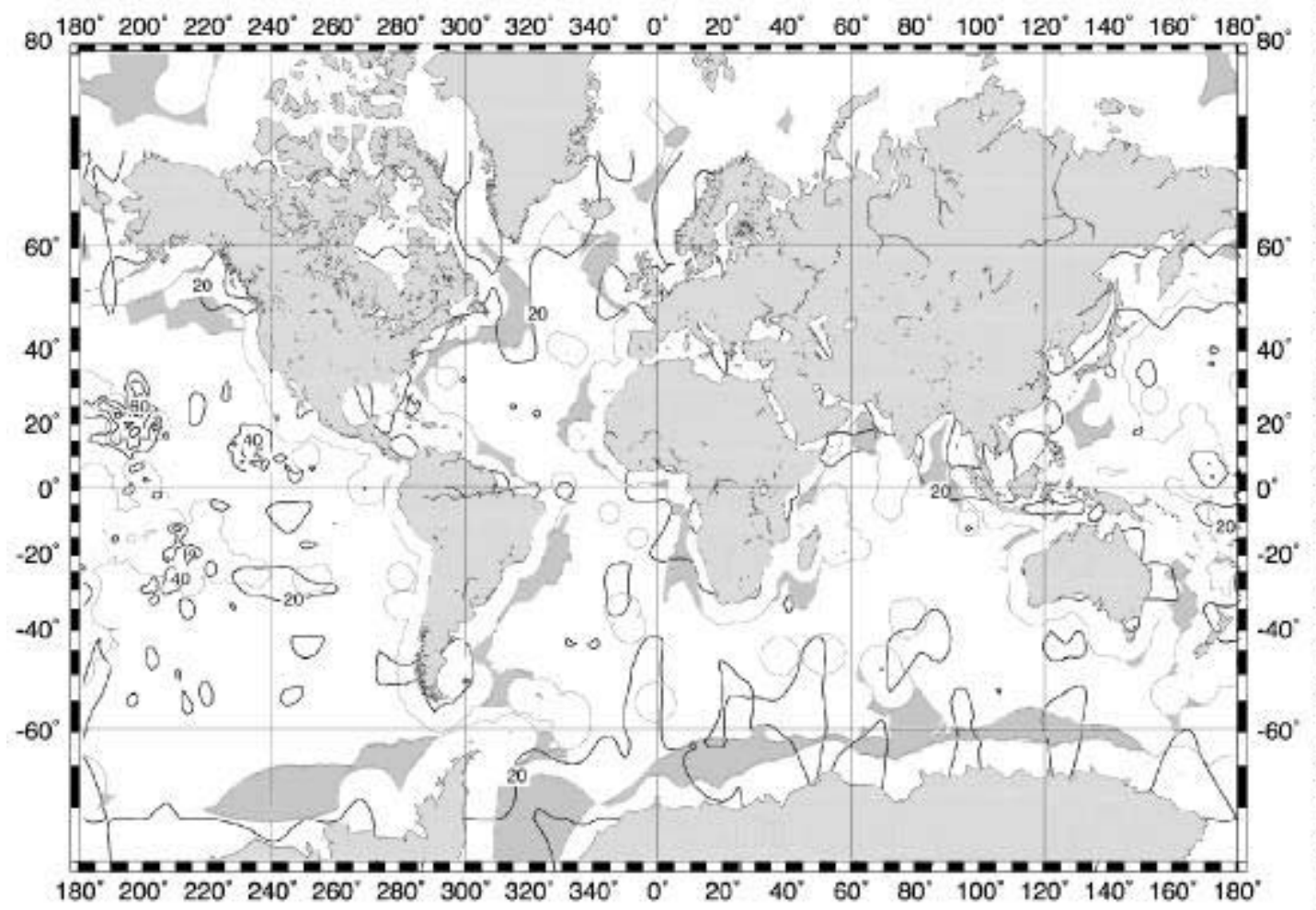

Figure 7 - Density of elemental cobalt (in $\mathrm{mg} / \mathrm{m}^{2}$ ) on the seafloor, contained in nodules and crusts, gridded on a $1^{\circ}$ latitude and longitude basis (from data compiled from the same sources cited on figure 3) and with reference to the ELCS regions (in grey) and EEZ areas (outlined by thin curved grey lines).

of up to $6 \mathrm{~kg} / \mathrm{m} 2$.

Manganese nodules, with up to 2 wt. $\%$ of combined nickel and copper and up to $4000 \mathrm{ppm}$ cobalt, are found in an area in the Indian Ocean that extends from $10^{\circ} \mathrm{S}$ to $25^{\circ} \mathrm{S}$ and $70^{\circ} \mathrm{E}$ to $86^{\circ} \mathrm{E}$ (Frazer \& Fisk, 1977; Frazer and Wilson, 1980). However, these have concentration of less than $1 \mathrm{~kg} / \mathrm{m} 2$.

Other areas to the south-west (between $40-60^{\circ} \mathrm{S}$ and $70-95^{\circ} \mathrm{E}$ ) and north-west (between $10-25^{\circ} \mathrm{S}$ and 95- $105^{\circ} \mathrm{E}$ ) of Australia have scattered concentrations of nodules up to $2 \mathrm{~kg} / \mathrm{m} 2$ (Cronan, 1980, 2000; Hayes et al.,1985; Gross and McLeod, 1987). However, their metal content appears to be generally low with combined copper and nickel of only 2 wt. \%. A more significant field of nodules lies in the western Pacific (between $20^{\circ} \mathrm{N}$ and the equator and $160-200^{\circ} \mathrm{E}$ ) where average densities are up to $6 \mathrm{~kg} / \mathrm{m} 2$. Here combined copper and nickel contents comprise 2-3 wt. $\%$, and cobalt concentrations are up to $8000 \mathrm{ppm}$. This corresponds to elemental abundance of copper, cobalt and nickel of up to $150 \mathrm{~g} / \mathrm{m} 2,25 \mathrm{mg} / \mathrm{m} 2$ and $0.05 \mathrm{~kg} / \mathrm{m} 2$ respectively.

Nodules are sparsely and irregularly distributed through broad areas of the Atlantic. Probably the most economically interesting concentrations are found on the Blake Plateau, in shallow water to the east of Florida. Here, nodules and crusts with high $\mathrm{Mn} / \mathrm{Fe}$ ratios make them economically attractive as a manganese resource (Manheim, 1972). In the Mediterranean Sea, nodules off the west coast of Italy are of special interest for similar reasons. Other areas near continental margins where nodules and crusts have high $\mathrm{Mn} / \mathrm{Fe}$ ratios include areas such as the southern and south-western African continental margin (Cronan, 1980; 2000; Glasby, 1977).

Although the mineralogy, composition and origin of manganese nodules are relatively well known, assessments of their resource potential are not well documented. Potential resource estimates for copper, nickel and cobalt in nodules were made during the 1960s and 1970s and are summarised in Volume I of the United Nations Seabed Mineral Series. However, most of the estimates of resource potential were based on a minimum abundance of $10 \mathrm{~kg} / \mathrm{m} 2$ and a minimum combined grade of $1.76 \mathrm{wt}$ \% copper and nickel. The abundance of nodules however, remains a major 
source of uncertainty and any global estimates must be subject to non-definable degree of error. Despite this, potential world wide resources of nodules have been estimated, and range from 14 to 99 billion tonnes (Gross \& McLeod, 1987).

While accepting the uncertainties and limitations of past and present resource estimates, using the methods described here it is possible to broadly estimate the resources held by manganese nodules and crusts within potential ELCS regions Table 3. The top ten countries that have the greatest resource potential of nodules and crusts in their ELCS, ranked in descending order are: the United States of America, Madagascar, Brazil, Antarctica, Argentina, Japan, South Africa, Canada and India, ranging from 1.86 billion tonnes to 0.33 billion tonnes respectively. Elemental resources for these ten countries range from: 330 million tonnes of manganese (for Antarctica) to 44.5 million tonnes (for India); 28.3 million tonnes of copper (for Antarctica) to 0.9 million tonnes (for India); 35.7 million tonnes of nickel (for Antarctica) to 2.2 million tonnes (for India); and 4458 tonnes of cobalt (for the USA) to 445 tonnes (for India). Even for those countries with the lowest abundance of nodules and crusts present in their ELCS, the elemental resources range from: 2.7 million tonnes of manganese (for Mauritania) to 11,408 tonnes (for Venezuela); 0.18 million tonnes of copper (for Guyana) to less than 1,500 tonnes (for Zaire); 0.15 million tonnes of nickel (for Guyana) to 2,852 tonnes (for Venezuela); and

\begin{tabular}{|c|c|c|c|c|c|c|c|}
\hline Country & $\begin{array}{c}\text { ELCS } \\
\text { (sq. km) }\end{array}$ & $\begin{array}{c}\text { Conc. } \\
(\mathrm{kg} / \mathrm{sq} . \mathrm{m})\end{array}$ & $\begin{array}{c}\text { Total } \\
\text { (kg) }\end{array}$ & Country & $\begin{array}{c}\text { To tal Area } \\
\text { (sq. km) }\end{array}$ & $\begin{array}{c}\text { Conc. } \\
(\mathrm{kg} / \mathrm{sq} . \mathrm{m})\end{array}$ & $\begin{array}{l}\text { Total } \\
\text { (kg) }\end{array}$ \\
\hline Angola & 251,305 & 0.25 & $62,826,138$ & Morocco & 824,562 & 0.25 & $206,140,415$ \\
\hline Antarctica & $5,418,265$ & 0.37 & $1,484,701,297$ & Mozam bique & 123,258 & 1 & $123,258,000$ \\
\hline Argentina & 239,319 & 1 & $239,319,000$ & Namibia & $1,111,735$ & 0.25 & $277,933,750$ \\
\hline Australia & 728,342 & 1 & $363,262,670$ & New Zeal and & 617,808 & 0.63 & $321,417,670$ \\
\hline Bangladesh & 969,982 & ND & 0 & Nigeria & 103,772 & ND & 0 \\
\hline Brazil & $1,964,494$ & 0.37 & $922,099,185$ & Norway & 158,920 & $\mathrm{ND}$ & 0 \\
\hline Burma & 46,203 & ND & 0 & Oman & 375,295 & 0.75 & $281,471,250$ \\
\hline Canada & $2,193,712$ & 0.5 & $436,144,640$ & P akistan & 41,255 & 0.75 & $30,940,905$ \\
\hline Congo & 14,652 & 0.25 & $3,663,000$ & Prillippines & 564,725 & 2 & $1,129,449,420$ \\
\hline Dermark & 237,431 & $\mathrm{ND}$ & 0 & Portugal & 123,476 & 1 & $123,476,000$ \\
\hline Equitorial Guinea & 15,566 & $\mathrm{ND}$ & 0 & Russia & 430,369 & $\mathrm{ND}$ & 0 \\
\hline France & 258,768 & 0.75 & $336,172,110$ & Senegal & 106,650 & 0.25 & $19,317,290$ \\
\hline French Guiana & 140,980 & 0.25 & $35,244,915$ & Seychelles & 321,039 & 0.25 & $80,259,750$ \\
\hline Gabon & 136,752 & 0.25 & $34,188,000$ & Sierr a Leone & 51,030 & 0.05 & $2,551,518$ \\
\hline Gambia & 10,662 & 0.25 & $2,665,582$ & Somalia & 242,676 & 0.5 & $121,337,985$ \\
\hline Ghana & 25,943 & $\mathrm{ND}$ & 0 & SOPAC & 324,192 & 1 & $100,077,000$ \\
\hline Greenland & 103,312 & ND & 0 & South Africa & 184,863 & 0.72 & $138,659,250$ \\
\hline Guinea & 27,897 & 0.05 & $1,394,871$ & Sri Lanka & 768,758 & ND & 0 \\
\hline Guinea Bissau & 38,359 & 0.05 & $1,917,947$ & Surinatme & 89,110 & 0.25 & $22,277,450$ \\
\hline Guyana & 61,003 & 0.25 & $15,250,628$ & Tanzaria & 55,681 & 0.5 & $27,840,520$ \\
\hline Iceland & 84,937 & 1 & $23,334,315$ & Togo & 15,566 & $\mathrm{ND}$ & 0 \\
\hline India & $1,011,832$ & ND & $646,031,250$ & Urited Kingdom & 243,679 & 0.25 & $60,919,750$ \\
\hline Ireland & 176,511 & 0.1 & $17,651,100$ & United States & $1,212,653$ & 1.5 & $1,860,660,625$ \\
\hline Japan & 339,701 & 2 & $679,402,580$ & USA (Guam) & 241,087 & 2 & $482,174,120$ \\
\hline Kenya & 20,782 & 0.5 & $10,390,995$ & Uruguay & 53,182 & 0.5 & $26,591,000$ \\
\hline Madagascar & $2,087,434$ & 1 & $2,087,434,000$ & $V$ enezuela & 1,141 & 0.25 & 285,208 \\
\hline Mauritania & 53,312 & 0.25 & $13,328,000$ & Zaire & 13,431 & 0.25 & $3,357,750$ \\
\hline Mauritius & 321,039 & 1.5 & $481,558,500$ & Total & $25,378,408$ & & $13,338,377,346$ \\
\hline
\end{tabular}

Table 3 - Global distribution, concentration and abundance of manganese nodules and crusts, located within the ELCS, apportioned to each coastal state $(\mathrm{ND}=$ not detected $)$. 
107 tonnes of cobalt (for Mauritania) to about 20 tonnes (for Gambia).

At the scale of this global study, it is not possible to determine specifically where resources contained in nodules and crusts occur at grades above or below economically viable cut-off limits (e.g. when considering recovery, transport and production costs against commodity prices). However, it is possible to rank countries according to the average grade of manganese nodules and crusts in their ELCS. These areas, on average, are characterised by higher grades and may in future have locations favourable for manganese nodule and crust recovery. The ten countries with the highest average grades of nodules and crusts (in tonnes per $\mathrm{km} 2$ ) are: the Philippines, Japan and Guam $(\sim 2,000)$, the USA $(\sim 1,500)$, Madagascar, Mozambique, Argentina, Fiji $(\sim 1,000)$, and South Africa ( 900). The Yemen, Pakistan, and Oman all have equal grades of $\sim 750$ tonnes per square kilometre. The Marshall Islands, Johnston Islands (U.S. EEZ), Kiribati, the Federated States of Micronesia, and French Polynesia are the Pacific Island areas with probably the greatest manganese crust resources (Gross \& McLeod, 1987; Kesler, 1994). However, of these, only the Marshall Islands' EEZ has been assessed in any great detail to date.

\section{Marine hydrocarbon deposits}

Generally, large quantities of hydrocarbons can be formed only at depths within sedimentary sequences greater than 1,000 - 2,000 meters. Formation of exploitable reservoirs of hydrocarbons requires migration (from their source rocks) to geological traps comprising a porous reservoir rocks and overlain by an impermeable horizon. Common geological traps for hydrocarbons include: shales, salt domes (evaporites), and anticlinal folds of permeable and non-permable strata. In addition to liquid hydrocarbons, natural gas is also common. Sedimentary sequences in excess of 1,000 $\mathrm{m}$ thick in areas of high-heat flow, comprising organic-rich layers overlain by porous rocks that are in turn overlain by domed impermeable strata provide ideal environments for hydrocarbon formation and retention.

In 1995, only ten offshore fields accounted for

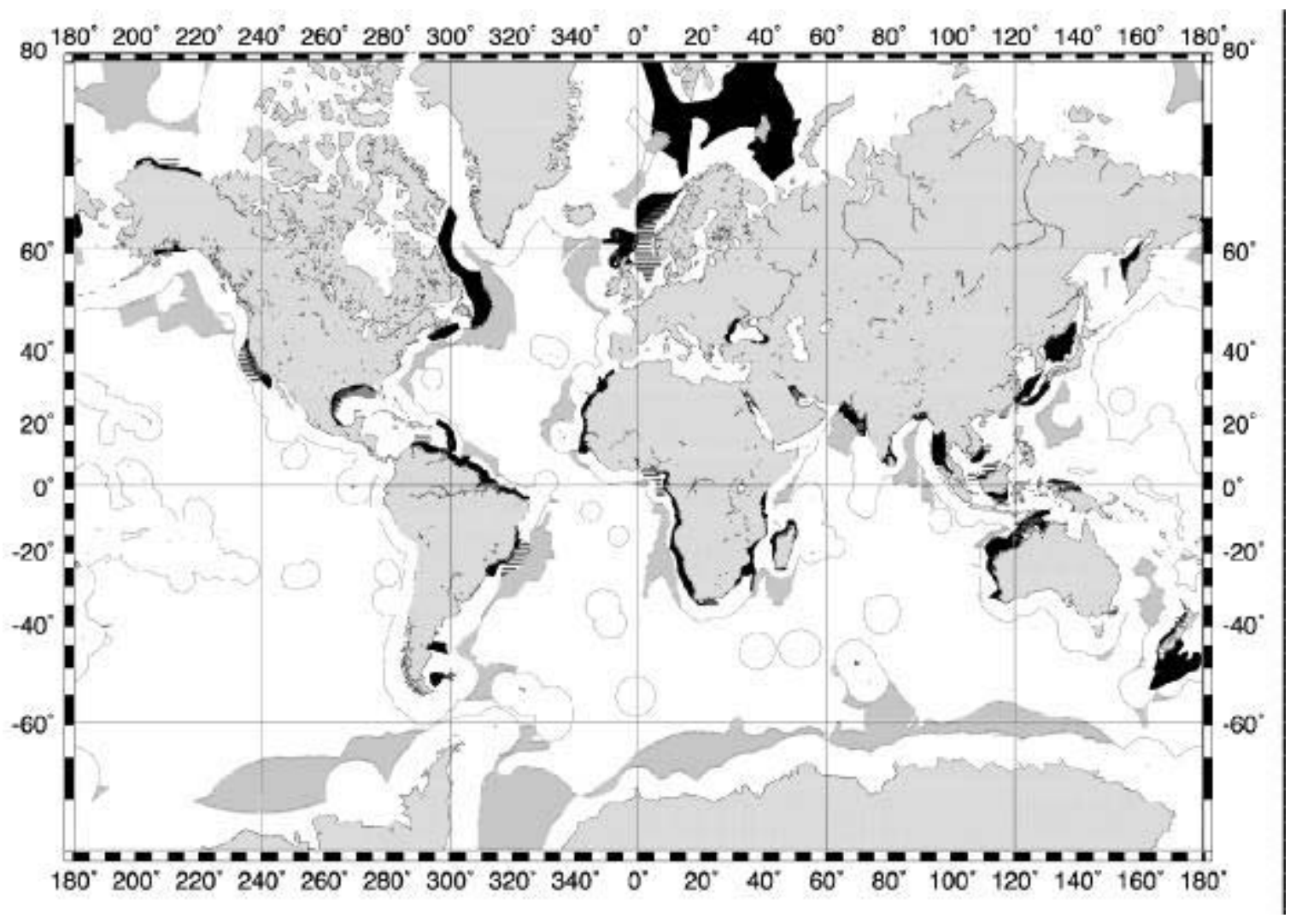

Figure 8 - Oil and Gas provinces of the world (in black - after Klett et al.,1997) and the main offshore areas where oil and gas are produced (striped - after IEA, 1996 and references therein) with reference to ELCS regions (in grey) and EEZ areas (outlined by thin curved grey lines). 
$25 \%$ of estimated world offshore production, while the 25 most productive fields accounted for over $40 \%$ (IEA, 1996). The estimated reserves of oil world wide at the beginning of the 21 st Century are about one trillion barrels. Of this amount, about 252 billion barrels $(25 \%)$ lie in marine environments. Similarly, the total world wide resources of natural gas are estimated at about 4,000 trillion cubic feet, of which about 26 percent are marine. However, offshore hydrocarbon resources may be ten times larger, in which case they are likely to provide the majority of future hydrocarbon production (IEA, 1996).

Figure 8 summarises the major offshore oil and gas provinces of the world (Klettet al. 1999; Meyer, 1981) in relation to a global sediment thickness model (compiled by NGDC, based on work by: Mathhias et al., 1988; Ludwig \& Houtz, 1979; Hayes \& La Brecque, 1991; Divins \& Rabinowitz, 1991; Divins $\&$ Eakins, in prep.). These reserves of oil and gas are located almost exclusively on the continental shelves and are characterised by sedimentary sequences greater than 1,000 $\mathrm{m}$ in thickness. Their location ranges from the continental slopes of northern Alaska to Tierra del Fuego and from the South China Sea to the Gulf of Mexico. However, with the exception of a small area offshore central western Africa, all of these areas lie within the EEZ but do not extend to the ELCS.

Of the twenty-five largest offshore production fields, eight are in the Persian Gulf and eight others are in the North Sea. The remaining ones are located in the Gulf of Mexico, East Asia, South Asia, South America, West Africa and North Africa. The IEA (1996) identify fifteen fields that produced in excess of $200 \mathrm{~kb} / \mathrm{d}$ (thousand barrels of oil equivalent per day) in 1995. Another thirty fields are estimated to have had production levels of more than $100 \mathrm{~kb} / \mathrm{d}$.

In the future, offshore oil supply growth is expected to occur increasingly from areas outside the North Sea and the Persian Gulf. By 2005, five fields, two off Brazil and one each in West African waters, the Gulf of Mexico and the Norwegian Sea, are expected to move into the top 25 producers, with several other potential major producers off West Africa and in the deep-water Gulf of Mexico approaching similar production levels (IEA, 1996).

A qualitative indication of resource potential, and hence a relative ranking of ELCS regions and their coastal states, can be made by comparing the known reserve province against the location of those countries with significant sedimentary sequence thickness (Klett et al., (1999). This shows the continental shelf and rise contains the largest accumulations of sediment (often in excess of $10 \mathrm{~km}$ ), that also have a high probably to include organic-rich source rocks deposited when the proto-ocean basins were narrow and had restricted circulation (Rona, 1969; Schneider, 1969). The abyssal plains probably contain insufficient thickness of sediments (less than $1 \mathrm{~km}$ ) to yield hydrocarbon accumulations. Parts of the deep trenches may be more favourable, as may some foundered remnants of continental blocks broken off during early rifting processes.

Areas that contain wide continental shelves with sediment thickness in excess of $1 \mathrm{~km}$, deposited in conditions favourable for hydrocarbon genesis, are shown on figure 9 . These occur throughout the subarctic (north of $60^{\circ} \mathrm{N}$ ) and include the coasts of Greenland, Norway, Alaska, northern Canada and Russia. In the Arctic Ocean, sedimentary thickness often exceed $4 \mathrm{~km}$. Similarly, much of the continental margin of Antarctica also contains sediment in excess of $2 \mathrm{~km}$ thick. Elsewhere, favourable offshore conditions occur along the Atlantic seaboards of North, Central and South America (including Mexico, Trinidad-Tobago, Venezuela, Guyana, Surinam, French Guiana, Brazil, Uruguay, Argentina), western Europe and Africa, Eastern Africa, the northern margin of the Indian Ocean, Indonesia and around Australia, New Zealand, off mainland China, Korea, Taiwan, and the Pacific seaboard of Russia (Sea of Okhotsk).

Small sub-sea basins that have a thick sequences of potentially organic-rich sediment, and hence large petroleum resources, include the Gulf of Mexico and the Caribbean Sea (2-6 km thickness), the Mediterranean Sea (up to $8 \mathrm{~km}$ ), the Black Sea and Caspian Sea $(4 \mathrm{~km})$, the Bering Sea, the Sea of Okhotsk, the Sea of Japan, the South China Sea, and the seas within the Indonesian Archipelago (all 2-4 $\mathrm{km})$. However, several of these favourable areas have water depths of as much as 5,500 meters and extend $1,500 \mathrm{~km}$ or more from shore, making hydrocarbon production difficult.

Table 4 shows the coastal states with potential ELCS that coincide with offshore sedimentary 


\begin{tabular}{|c|c|c|c|c|c|c|c|}
\hline Country & $\begin{array}{l}\text { ELCS } \\
\text { area }\end{array}$ & $\begin{array}{l}\text { To tal area } \\
=1 \mathrm{~km} \text { sed. }\end{array}$ & $\begin{array}{c}\% \text { area } \\
=1 \mathrm{~km} \text { sed. }\end{array}$ & Country & $\begin{array}{c}\text { ELCS } \\
\text { area }\end{array}$ & $\begin{array}{l}\text { To tal area } \\
=1 \mathrm{~km} \text { sed. }\end{array}$ & $\begin{array}{c}\% \text { area } \\
=1 \mathrm{~km} \text { sed. } .\end{array}$ \\
\hline Angola & 251,305 & 163,348 & $65 \%$ & Morocco & 824,562 & 329,825 & $40 \%$ \\
\hline Antarctica & $5,418,265$ & $2,133,702$ & $39 \%$ & Mozatn bique & 123,258 & 123,258 & $100 \%$ \\
\hline Axgentina & 239,319 & 167,523 & $70 \%$ & Natnibia & $1,111,735$ & 277,934 & $25 \%$ \\
\hline Australia & 728,342 & 174,640 & $24 \%$ & N ew Zeal and & 617,808 & 228,106 & $37 \%$ \\
\hline Bangladesh & 969,982 & 969,982 & $100 \%$ & Nigeria & 103,772 & 103,772 & $100 \%$ \\
\hline Brazil & $1,964,494$ & 862,567 & $44 \%$ & Norway & 158,920 & 68,522 & $43 \%$ \\
\hline Burma & 46,203 & 46,203 & $100 \%$ & Oman & 375,295 & 375,295 & $100 \%$ \\
\hline Canada & $2,193,712$ & 948,072 & $43 \%$ & Pakistan & 41,255 & 41,255 & $100 \%$ \\
\hline Congo & 14,652 & 14,652 & $100 \%$ & Philippines & 564,725 & 0 & $0 \%$ \\
\hline Denmark & 237,431 & 130,587 & $55 \%$ & Portugal & 123,476 & 0 & $0 \%$ \\
\hline Equ. Guinea & 15,566 & 15,566 & $100 \%$ & Russia & 430,369 & 408,124 & $95 \%$ \\
\hline Fr ance & 258,768 & 112,057 & $43 \%$ & Senegal & 106,650 & 53,678 & $50 \%$ \\
\hline French G uyana & 140,980 & 98,686 & $70 \%$ & Seychelles & 321,039 & 0 & $0 \%$ \\
\hline Gabon & 136,752 & 123,077 & $90 \%$ & Sierra Leone & 51,030 & 38,273 & $75 \%$ \\
\hline Gambia & 10,662 & 0 & $0 \%$ & Somalia & 242,676 & 242,676 & $100 \%$ \\
\hline Ghana & 25,943 & 20,754 & $80 \%$ & SOPAC & 324,192 & 100,852 & $31 \%$ \\
\hline Greenland & 103,312 & 51,656 & $50 \%$ & South Africa & 184,863 & 108,537 & $59 \%$ \\
\hline Guinea & 27,897 & 11,159 & $40 \%$ & Sri Lanka & 768,758 & 653,445 & $85 \%$ \\
\hline Guinea Bissau & 38,359 & 24,933 & $65 \%$ & Suriname & 89,110 & 49,010 & $55 \%$ \\
\hline Guryana & 61,003 & 54,902 & $90 \%$ & Tanzaria & 55,681 & 55,681 & $100 \%$ \\
\hline Iceland & 84,937 & 53,389 & $63 \%$ & Togo & 15,566 & 15,566 & $100 \%$ \\
\hline India & $1,011,832$ & 968,764 & $96 \%$ & $\mathrm{UK}$ & 243,679 & 85,288 & $35 \%$ \\
\hline Ir el and & 176,511 & 61,779 & $35 \%$ & USA & 971,566 & 751,711 & $77 \%$ \\
\hline Japan & 339,701 & 0 & $0 \%$ & USA (Guam) & 241,087 & 0 & $0 \%$ \\
\hline Kenya & 20,782 & 20,782 & $100 \%$ & Unuguay & 53,182 & 53,182 & $100 \%$ \\
\hline Madagascar & $2,087,434$ & 626,230 & $30 \%$ & Venezuela & 1,141 & 1,141 & $100 \%$ \\
\hline Mauritania & 53,312 & 53,312 & $100 \%$ & Zaire & 13,431 & 13,431 & $100 \%$ \\
\hline Mauritius & 321,039 & 0 & $0 \%$ & Total & & $12,086,883$ & \\
\hline
\end{tabular}

Table 4 - Area $(\mathrm{km})$, located within the ELCS apportioned to each coastal state, containing sediment thickness in excess of $1 \mathrm{~km}$.

sequences thickness in excess of $1 \mathrm{~km}$. Against each state is the area of its ELCS and its percentage that contains sediment thickness greater than $1 \mathrm{~km}$. Although this is not an assessment of the resource volume of hydrocarbons, the table serves to identify those coastal states with ELCS areas that may host significant hydrocarbon resources.

The ten countries, with the largest areas (cited in brackets in millions of km2) of their ELCS' containing sedimentary sequences in excess of $1 \mathrm{~km}$ thick, and hence having potential hydrocarbon resources are: Antarctica (2.23), Canada (0.95), Brazil (0.95), USA (0.75), Sri Lanka (0.65), India (0.58), Argentina (0.52), Madagascar (0.49), Russia (0.41) and Morocco (0.33). The bottom ranked countries are: Kenya (0.02), Sierra Leone (0.02), the Congo
Republic (0.015), Zaire (0.013), Guinea (0.012), Bangladesh (0.005), Mauritania (0.003), Equatorial Guinea, Tonga and Venezuela (each with 0.001).

High resource potential, that coincides with ELCS regions, is also found throughout the Atlantic seaboard of North and South America (including the Labrador Sea); Antarctica; northern and western Norway; south and west of the United Kingdom and Ireland; parts of north-west Africa; south-west Africa, south-east Africa and East of the Horn of Africa; South of Pakistan; East and West of India; South of Tasmania (Australia); North of New Zealand and East of Australia; the Sea of Okhotsk; and the Alaskan Arctic seaboard. In all of these areas, conventional hydrocarbon resources are considerable. However, exploration and recovery conditions are likely to vary 


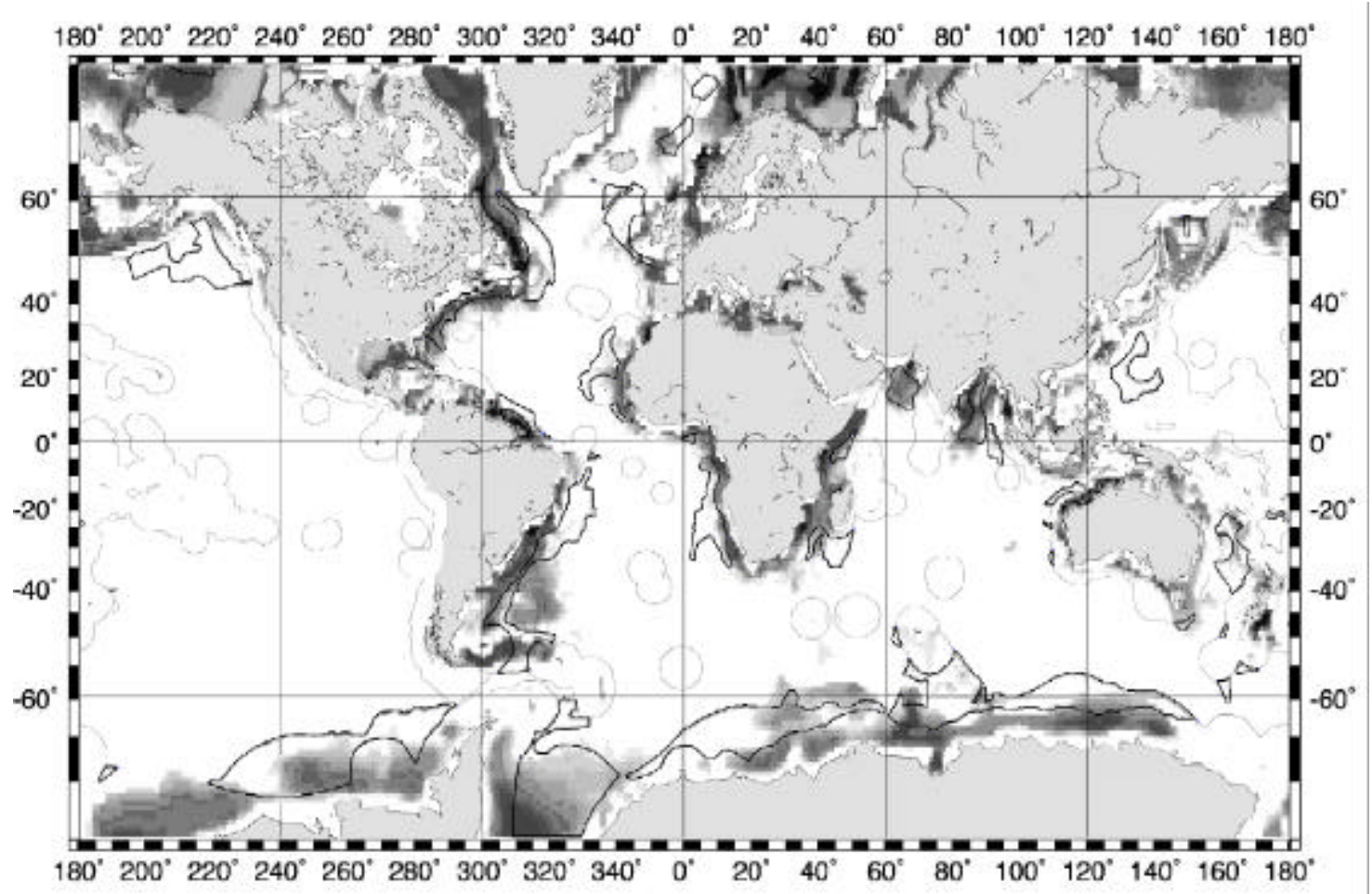

Figure 9 - Map showing conventional hydrocarbon potential (qualitative and relative only) based on sediment thickness, crustal age and crustal type with reference to ELCS regions (outlined in black) and EEZ areas (outlined by thin curved grey lines). High potential is represented by increasingly darker greys.

enormously, effecting their potential value.

\section{Marine gas hydrate deposits}

Gas hydrate is a crystalline compound composed of gas molecules, normally methane, en-caged within water molecules to form a solid similar to ice (Kvenvolden, 1993). It forms within pore space and cements sedimentary grains together. On dissociation, solid hydrate yields approximately 164 times its own volume of methane gas (at standard atmospheric pressure and temperature).

Gas hydrates are estimated to hold many times more methane than presently exists in the atmosphere and up to twice the amount of energy of all fossil carbon-based fuels combined (McIver, 1981; Gornirz and Fung, 1994). Methane is also highly effective greenhouse gas. Because hydrate reservoirs are extremely sensitive to climate change they have positive feedback mechanisms that can catastrophically accentuate global warming. The presence of subsurface hydrate is also directly linked to major reductions in seafloor stability that influences the frequency and magnitude of submarine landslides and their associated tidal surges. Such landslides can trigger further hydrate dissociation, increasing the flux of methane into the atmosphere. However, there is considerable uncertainty in estimates of the global extent of gas hydrates, partly because of the difficulty in locating deposits in the sediment column beneath the seafloor.

Hydrates form and accumulate where marine sediments contain suitable and sufficient dissolved gas and where the geothermal gradient allows conditions that are within the stability field of the hydrate. As a result, they occur widely in nature, mainly beneath the seafloor in deep-sea sediments but also close to the seabed in cold, shallow arctic seas. The source of the dissolved gas is biogenic and thermogenic, from breakdown of organic matter trapped within marine sediment. Therefore, the unoxidsed organic carbon content of the sediment is also a significant factor in determining the potential for gas hydrate generation.

The stability conditions for methane hydrate may be met at water depths greater than $500 \mathrm{~m}$ on the continental slope and continuing to a depth beneath 


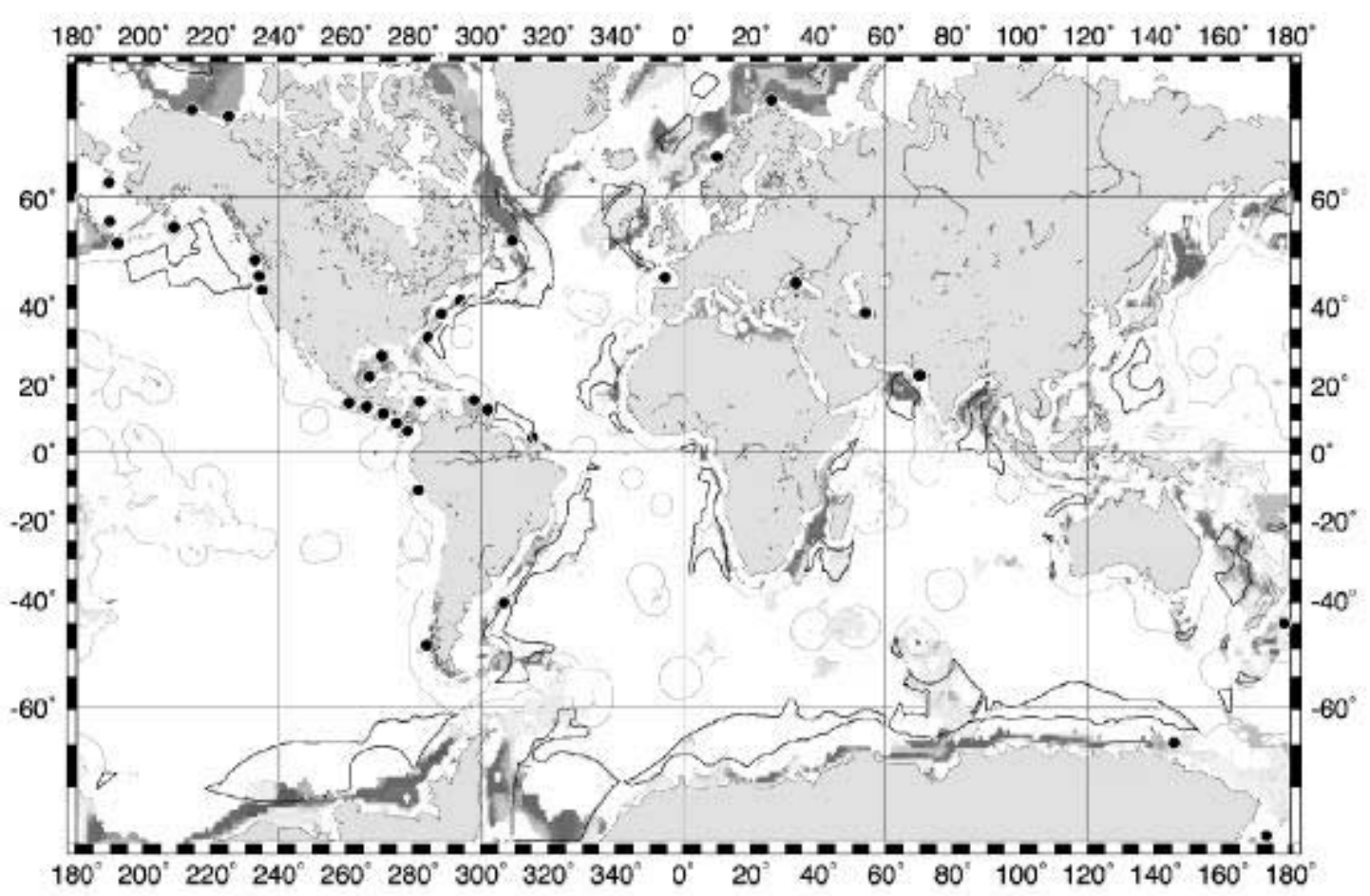

Figure 10 - Map showing gas hydrate potential (qualitative and relative only) based on sediment thickness, crustal age, heat flow and water depths greater than $500 \mathrm{~m}$, with reference to ELCS regions (outlined in black) and EEZ areas (outlined by thin curved grey lines). High potential is represented by increasingly darker greys. Also shown are locations (filled black circles) where gas hydrates have been recovered.

the deep seafloor determined by the geothermal gradient. The actual depth at which hydrate is stable also depends on bottom water temperature. Additionally, the introduction of higher molecularweight gases (ethane or propane) allows a mixed gas hydrate to form at lower pressures and therefore to be stable in shallower water or at higher temperature (Kvenvolden, 1993). However, the presence of brine in sediment pore water decreases the stability of gas hydrate, requiring deeper and colder conditions for formation.

The methane in gas hydrate forms naturally by organic decay in the thick sediments normally found in the deep water adjacent to continental margins. At depth in the sediment the temperature becomes too high for hydrate to be stable and the abrupt change of physical properties inherent with free gas in the sediment pore spaces generates a seismic reflectorthe Bottom Simulating Reflector (BSR). Although these have been used to identify gas hydrate on seismic reflection profiles for some time, there remains some uncertainty whether every BSR is associated with gas hydrate. However, the occurrence of BSRs in combination with suitably stable conditions is a useful indicator for the presence of hydrate. Despite this, there has been little effort to compile the distribution of BSRs on a world wide basis (Max, 1990; Lee et al, 1994; Miles, 1995).

Figure 10 shows the world wide locations of all known gas hydrates (Max, 1990; Lee et al, 1994; Kesler, 1994). The figure also shows the areas where water depths range from 500 to $4000 \mathrm{~m}$ on seafloor that is older than $30 \mathrm{Ma}$. These depths are appropriate for gas hydrate formation and the age of the underlying oceanic lithosphere is such that heat flow, based on plate cooling models, is expected to be low enough for hydrate stability (Miles, 1995).

Gas hydrates are known from the Atlantic and Pacific margins of both North and South America, especially at equatorial latitudes. They are also found around off the coast of Canada, Alaska, off the West coast of Norway, the Black Sea and off the coast of Pakistan. Isolated occurrences are also found off New Zealand and Antarctica (Max, 1990; Lee et al., 1994).

Because BSRs potentially indicate only the 
presence of a gas hydrate layer, and not the total volume of hydrate or the volume of free gas in the sediment beneath the layer, it is not possible to estimate the potential resource that gas hydrates offer with any certainty. Instead, it is only possible to estimate the areas where conditions for hydrate formation are favourable (Kvenvolden et al., 1993 and others see below). Table 5 shows a compilation of current estimates for global methane gas and carbon resources in oceanic and continental settings. Although considerable uncertainty exists about the total gas resource potential of hydrates, it would appear that the oceanic potential is considerable.

Extrapolation from the few documented locations where gas hydrates have been recorded is very likely to lead to an underestimate of the total world wide occurrence. From considerations of the stability condition for hydrate, the deposit is likely to occur everywhere the seafloor exceeds $500 \mathrm{~m}$ (or $300 \mathrm{~m}$ in high latitudes), and where there is a source of unoxidsed organic carbon in marine sediments (Miles, 1985; Collett, 1992). The greater the thickness of marine sediments, the greater the likelihood of there being a suitable source material for the biogenic or thermogenic production of methane.

Figure 10 also shows the location of areas favourable for gas hydrate formation, and hence with potential for hydrate resources. These areas lie in water depths greater than $500 \mathrm{~m}$, on crust less than $30 \mathrm{Ma}$ old and include data on sediment thickness. Areas with relatively high gas hydrate potential are coloured dark grey, and those with low potential are coloured light grey. These are only qualitative, relative indications of hydrate potential and are not indicative of actual known or indicated volumes.

The areas identified on Figure 10 as having high gas hydrate potential coincide with those localities where gas hydrates have been found already. Elsewhere, high potential exists in the Arctic and Antarctic, Bearing Sea, Barents Sea, Labrador Sea, eastern margin of North and South America, the African margin, Mediterranean Sea, Black Sea, off Pakistan and eastern India, north-west Australia, south-west New Zealand and the Sea of Okhotsk, Japan and the western European Margin.

\section{CONCLUSIONS}

We present here an evaluation of global offshore non-living resources based on known occurrences and reserves, the geologic environments favourable for formation, models for sediment type and thickness, and basement composition. These resources are examined in relation to offshore areas that lie beyond outer limits of exclusive economic zones (EEZ), but within areas that have the potential to be claimed as extended legal continental shelf(ELCS), under the criteria established by the United Nations Convention on the Law of the Sea, Article 76 (1982). Eight different types of non-living resources are assessed. Table 6 gives a summary of these resources, their quantity, and estimated grade for the nation states that

\begin{tabular}{|c|c|c|c|}
\hline $\begin{array}{l}\text { Methane gas } \\
\mathrm{m}^{3} \times 10^{15} \\
\text { Oceanic sedi }\end{array}$ & $\begin{array}{l}\text { Methane gas } \\
\text { Tef } \times 10^{5}\end{array}$ & $\begin{array}{l}\text { Methane carb on } \\
\operatorname{kg} \times 10^{15}\end{array}$ & Reference \\
\hline \multicolumn{4}{|c|}{ Oceanic sediments } \\
\hline 3.1 & 1.1 & 1.7 & McIver (1981) \\
\hline $5-25$ & $1.8-8.8$ & $2.7-13.7$ & Trofimuk et al. (1977) \\
\hline 7600 & 2700 & 4100 & Dobrynin et al. (1981) \\
\hline 17.6 & 6.2 & 11 & Kvenv olden (1988) \\
\hline 19.5 & 6.9 & 11 & MacDonald (1990) \\
\hline $26.4-139.1$ & 9.3 & 49.1 & Gornitz \& Fung (1994) \\
\hline \multicolumn{4}{|c|}{ Continental sediments } \\
\hline 0.014 & 0.005 & 7.5 & Meyer (1981) \\
\hline 0.031 & 0.011 & 17 & Mclver (1981) \\
\hline 0.057 & 0.02 & 31 & Trofimuk et al. (1977) \\
\hline 34 & 12 & 1800 & Dobrynin et al. (1981) \\
\hline--- & --- & 400 & MacDonald (1990) \\
\hline
\end{tabular}

Table 5 - Estimates of methane gas and methane carbon resource contained in continental and marine gas hydrate accumulations (after Dobrynin, 1981; Kvenvolden, 1993; Prensky, 1995; MacDonald, 1990). (Tcf = trillion cubic feet). 


\begin{tabular}{|c|c|c|c|c|c|c|c|c|c|c|c|c|c|}
\hline Country & \begin{tabular}{|c|} 
ELCS \\
Area \\
(sq. lemu
\end{tabular} & $\begin{array}{c}\text { Placer } \\
\text { Dep osits }\end{array}$ & \begin{tabular}{|c|} 
Phosphorite \\
Deposits
\end{tabular} & $\begin{array}{c}\text { Evaporite } \\
\text { Deposits }\end{array}$ & $\begin{array}{c}\text { PMS } \\
\text { Deposits }\end{array}$ & $\begin{array}{c}\text { nodules + } \\
\text { crusts } \\
\text { (tonnes) }\end{array}$ & $\begin{array}{c}\text { nodules }+ \\
\text { crusts } \\
\text { (tonnes/sq. } \\
\text { km) }\end{array}$ & $\begin{array}{c}\text { Total Mn } \\
\text { Metal } \\
\text { (tonnes) }\end{array}$ & $\begin{array}{c}\text { Total Cu } \\
\text { Metal } \\
\text { (tonnes) }\end{array}$ & $\begin{array}{c}\text { TotalNi } \\
\text { Metal } \\
\text { (tonnes) }\end{array}$ & $\begin{array}{c}\text { Total Co } \\
\text { Metal } \\
\text { (tonnes) }\end{array}$ & \begin{tabular}{|l|} 
oil \& gas \\
(BBOE)
\end{tabular} & \begin{tabular}{|c|} 
gas \\
hydrates \\
(BBOE)
\end{tabular} \\
\hline Angola & \begin{tabular}{|l|}
251,305 \\
\end{tabular} & ND & ND & ND & ND & $62,826,138$ & 250 & $12,565,228$ & 753,914 & $1,256,523$ & 1,257 & 0.1 & 0.1 \\
\hline Antarctica & $5,418,265$ & $\mathrm{ND}$ & ND & ND & ND & $1,484,701,297$ & 680 & $156,216,951$ & $21,338,635$ & $26,460,333$ & 4,178 & 20 & 30 \\
\hline Argentina & 239,319 & ND & $\mathrm{P}$ & ND & ND & $239,319,000$ & 1,000 & $59,829,750$ & $2,871,828$ & $1,794,893$ & 957 & 6 & 9 \\
\hline Australia & 728,342 & ND & $\mathrm{P}$ & $\mathrm{P}$ & ND & $363,262,670$ & 1,000 & $51,642,810$ & $2,639,762$ & $5,347,823$ & 720 & 1 & 1 \\
\hline Bangladesh & 969,982 & $\mathrm{ND}$ & ND & ND & $\mathrm{ND}$ & 0 & ND & 0 & 0 & 0 & 0 & 1 & ND \\
\hline Brazil & $1,964,494$ & ND & $\mathrm{P}$ & ND & ND & $922,099,185$ & 500 & $181,986,440$ & $14,512,996$ & $8,473,511$ & 5,412 & 10 & ND \\
\hline Burma & 46,203 & ND & ND & ND & ND & 0 & $\mathrm{ND}$ & 0 & 0 & 0 & 0 & 2 & 4 \\
\hline Canada & $2,193,712$ & ND & $\mathrm{ND}$ & ND & $\mathrm{ND}$ & $436,144,640$ & 500 & $|130,843,392|$ & $4,707,501$ & $8,722,893$ & 1,745 & 3 & 10 \\
\hline Congo & 14,652 & ND & $\mathrm{ND}$ & ND & ND & $3,663,000$ & 250 & 732,600 & 29,304 & 73,260 & 15 & 0.1 & ND \\
\hline Denumark & 237,431 & $\mathrm{ND}$ & $\mathrm{ND}$ & ND & $\mathrm{ND}$ & 0 & $\mathrm{ND}$ & 0 & 0 & 0 & 0 & 1.5 & ND \\
\hline Equatorial Guinea & 15,566 & ND & $\mathrm{ND}$ & ND & $\mathrm{ND}$ & 0 & ND & 0 & 0 & 0 & 0 & 1 & ND \\
\hline France & 258,768 & $\mathrm{ND}$ & $\mathrm{ND}$ & ND & ND & $336,172,110$ & 1,500 & $11,205,737$ & $1,120,574$ & $4,482,205$ & 2 & $\mathrm{ND}$ & 0 \\
\hline French Guyana & 140,980 & $\mathrm{ND}$ & $\mathrm{HD}$ & ND & ND & $35,244,915$ & 250 & $1,409,797$ & 422,939 & 0 & 282 & 0.1 & HD \\
\hline Gabon & 136,752 & $\mathrm{ND}$ & $\mathrm{ND}$ & ND & $\mathrm{ND}$ & $34,188,000$ & 250 & $6,837,600$ & 273,504 & 273,504 & 137 & 1 & $\mathrm{ND}$ \\
\hline Gambia & 10,662 & ND & ND & $\mathrm{P}$ & ND & $2,665,582$ & 250 & 533,116 & 21,325 & 10,662 & 21 & 0.1 & HD \\
\hline Ghana & 25,913 & ND & ND & ND & ND & 0 & ND & 0 & 0 & 0 & 0 & 8 & ND \\
\hline Greenland & 103,312 & ND & ND & ND & $\mathrm{ND}$ & 0 & MD & 0 & 0 & 0 & 0 & 0.5 & 1 \\
\hline Guinea & 27,897 & $\mathrm{ND}$ & ND & ND & ND & $1,394,871$ & 50 & 278,974 & 55,795 & 27,897 & 28 & 0.05 & HD \\
\hline Guinea Bissau & 38,359 & ND & ND & ND & ND & $1,917,947$ & 50 & 383,589 & 76,718 & 38,359 & 38 & 0.05 & ND \\
\hline Guyana & 61,003 & ND & ND & ND & ND & $15,250,628$ & 250 & $6,100,251$ & 183,008 & 61,003 & 61 & 0.1 & ND \\
\hline Iceland & 84,937 & ND & $\mathrm{ND}$ & ND & ND & $23,334,315$ & 1,000 & $4,386,865$ & 93,337 & 413,487 & 88 & ND & 0 \\
\hline India & $1,011,832$ & ND & $\mathrm{ND}$ & ND & $\mathrm{ND}$ & $646,031,250$ & 750 & $86,137,500$ & $1,722,750$ & $4,306,875$ & 12,921 & 2 & 4 \\
\hline Ireland & 176,511 & ND & ND & ND & ND & $17,651,100$ & 100 & $3,530,220$ & 176,511 & 176,511 & 177 & 3 & 2 \\
\hline Japan & 339,701 & $\mathrm{ND}$ & $\mathrm{ND}$ & $\mathrm{ND}$ & ND & $679,402,580$ & 2,000 & $67,940,258$ & $3,397,013$ & 679,403 & 2,718 & $\mathrm{ND}$ & 2 \\
\hline Kenya & 20,782 & $\mathrm{ND}$ & ND & $\mathrm{ND}$ & ND & $10,390,095$ & 500 & $1,039,100$ & 41,564 & 10,391 & 10 & 0.3 & 1 \\
\hline Madagasear & $2,087,434$ & $\mathrm{ND}$ & ND & $\mathrm{ND}$ & ND & $2,087,434,000$ & 1,000 & $417,486,800$ & $10,437,170$ & $10,437,170$ & 10,437 & 0.5 & 1 \\
\hline Mauritania & 53,312 & $\mathrm{ND}$ & $\mathrm{ND}$ & $\mathrm{P}$ & ND & $13,328,000$ & 250 & $2,665,600$ & 106,624 & 53,312 & 107 & 0.1 & ND \\
\hline Mauritus & 321,039 & ND & ND & ND & ND & $481,558,500$ & 1,500 & $128,415,600$ & $3,210,390$ & $16,051,950$ & 2,568 & 0.1 & 0 \\
\hline Morocco & 824,562 & ND & ND & ND & ND & $206,140,415$ & 250 & $41,228,083$ & $1,649,123$ & 824,562 & 1,649 & 0.1 & ND \\
\hline Mnzambique & 123,258 & ND & ND & ND & ND & $123,258,000$ & 1,000 & $24,651,600$ & 616,290 & 616,290 & 616 & 0.5 & 1 \\
\hline Namihia & $1,111,735$ & ND & ND & ND & NI & $277,933,750$ & 250 & $55,586,750$ & $3,782,145$ & $5,558,675$ & 3,335 & 0.05 & 0 \\
\hline New 7ealand & $613,8 \cap 8$ & ND & Nח & Nח & ND & $321,413,670$ & $1, \mathrm{n} \cap \mathrm{n}$ & $82,831,991$ & $1,901,053$ & $5,319,293$ & 2,189 & $n 2$ & ND \\
\hline Nigeria & 103,772 & ND & ND & ND & ND & 0 & ND & 0 & 0 & 0 & 0 & 1 & 1 \\
\hline Nonway & 158,920 & ND & ND & ND & ND & 0 & ND & 0 & 0 & 0 & 0 & 2 & 4 \\
\hline Oman & 375,295 & ND & ND & $\mathrm{ND}$ & ND & $281,471,250$ & 750 & $37,529,500$ & 750,590 & $1,876,475$ & 1,501 & 2 & ND \\
\hline Pakistan & 41,255 & ND & ND & ND & ND & $30,940,905$ & 750 & $4,125,454$ & 82,509 & 206,273 & 165 & 0.5 & ND \\
\hline Philippines & 564,725 & ND & $\mathrm{ND}$ & ND & ND & $1,129,4$ & 2,000 & 112944,942 & $4,517,798$ & 5,64 & 1,129 & 0 & ND \\
\hline Portugal & 123,4 & ND & ND & ND & $\mathrm{P}$ & $123,476,000$ & 1,000 & $12,347,600$ & $\begin{array}{l}493,904 \\
\end{array}$ & 123,476 & 185 & 0 & 0 \\
\hline Russia & 430,369 & ND & ND & ND & ND & 0 & ND & 0 & 0 & 0 & 0 & 10 & 15 \\
\hline Senegal & 106,650 & $\mathrm{ND}$ & $\mathrm{ND}$ & $\mathrm{P}$ & ND & $19,317,290$ & 250 & $5,332,490$ & 139.848 & 106,650 & 213 & 0.05 & ND \\
\hline Sexchelles & 321,039 & ND & $\mathrm{ND}$ & ND & ND & $80,259,750$ & 250 & $16,051,950$ & $1,605,195$ & $16,051,950$ & 321 & 0.1 & 0 \\
\hline Sierra Leone & 51,030 & ND & $\mathrm{N}$ & $\mathrm{N}$ & NI & & 50 & & & & 51 & 0.05 & ND \\
\hline Somalia & 242,676 & $\mathrm{ND}$ & $\mathrm{ND}$ & $\mathrm{ND}$ & ND & $121,337,985$ & 500 & $12,133,799$ & 485,352 & 242 & 485 & 1.5 & 3 \\
\hline SOPAC & 324,192 & ND & $\mathrm{ND}$ & ND & ND & $100,077,000$ & 1,000 & $15,011,550$ & 500,385 & $3,002,310$ & 300 & 0.1 & 0 \\
\hline South Africa & 184,863 & $\mathrm{ND}$ & ND & NI & NL & $138,659,250$ & 1,000 & $27,731,850$ & $1,109,130$ & 924,315 & 370 & 0.2 & 0 \\
\hline Sri Larka & 768,758 & ND & ND & ND & ND & 0 & ND & 0 & 0 & 0 & 0 & 0.25 & 1 \\
\hline Suriname & 89,110 & $\mathrm{ND}$ & $\mathrm{ND}$ & $\mathrm{ND}$ & ND & $22,277,450$ & 250 & $1,782,196$ & 267,329 & 89,110 & 89 & 5 & ND \\
\hline Tanzaria & 55,681 & ND & ND & ND & ND & $27,840,520$ & 50 & $2,784,052$ & 111,362 & 55,681 & 56 & 2.5 & 5 \\
\hline Togo & 15,566 & $\mathrm{ND}$ & $\mathrm{ND}$ & $\mathrm{ND}$ & ND & 0 & NI & 0 & 0 & 0 & 0 & 1 & ND \\
\hline United Kingdom & 243,679 & ND & ND & ND & ND & $60,919,750$ & 250 & $12,183,950$ & 243,679 & 243,679 & 244 & 1.5 & 2 \\
\hline United States & $1,212,653$ & ND & $\mathrm{ND}$ & ND & ND & $1,860,660,625$ & 2,500 & $182,134,120$ & $8,999,262$ & $12,186,013$ & 5,409 & 10 & 20 \\
\hline USA (Guam) & 241,087 & $\mathrm{ND}$ & $\mathrm{ND}$ & $\mathrm{ND}$ & ND & $482,174,120$ & 2,000 & $48,217,400$ & $2,410,871$ & $2,410,871$ & 1,205 & 0.01 & ND \\
\hline Uruguay & 53,182 & ND & ND & ND & ND & $26,591,000$ & 500 & $5,318,200$ & 425,456 & 531,820 & 106 & 0.5 & ND \\
\hline Venezuela & 1,141 & ND & ND & ND & ND & 285,208 & 250 & 11,408 & 3,422 & 1,141 & 1 & 5 & ND \\
\hline Zaire & 13,431 & ND & ND & ND & $\mathrm{ND}$ & $3,357,750$ & 250 & 671,550 & 13,431 & 67,155 & 13 & 0.2 & ND \\
\hline totak & $2.5 \times 10^{7}$ & 0 & 0 & 0 & 0 & $1.3 \times 10^{10}$ & & $2.0 \times 10^{8}$ & $1.0 \times 10^{8}$ & $1.5 \times 10^{8}$ & 63,512 & 106 & 115 \\
\hline
\end{tabular}

Table 6 - Compilation of offshore resources held within the areas that have the potential to lie within the extended "legal" continental shelf. The estimates are based on the methodologies described in the text. Symbols: ND - not detected, B.B.O.E. - billion barrels of oil equivalent, PMS - polymetalic sulphide

have potential claim to ELCS regions.

Placer deposits comprising heavy minerals, gold and diamonds are limited to near-shore areas and have negligible resource potential in the ELCS regions. Similarly, phosphorites occur in the equatorial oceans, mainly between $400 \mathrm{~m}$ and $1,500 \mathrm{~m}$ depth, but have limited resource potential in ELCS areas. Evaporite deposits occur on many continental margins. However, they only overlap with ELCS regions off eastern North America and western central Africa, where their resource potential is low. With the exception of the
West Pacific and off the western coast of North America, polymetallic sulphides (PMS) resources, which are formed at volcanically active plate boundaries, are generally low in all ELCS regions.

The major resource potential within the ELCS regions is held in iron-manganese nodules and crusts, oil, gas and gas hydrates. There are four elemental metals comprising the main components of value in manganese nodules and crusts: manganese, copper, nickel and cobalt. World wide, the total mass of nodules and crusts within ELCS regions is $13 \times 109$ 
tonnes. Of these, their metal content amounts to: $2 \mathrm{x}$ 109 tonnes of manganese, $14.5 \times 107$ tonnes of nickel, 107 tonnes of copper and 6.4 x 104 tonnes of cobalt. Conventional oil and gas comprise an estimated 106 b.b.o.e. (billion barrels of oil equivalent) with a similar estimate of 115 b.b.o.e. for gas hydrates. In total, the resource potential (excluding recovery and production costs) contained within the ELCS regions of the world amounts to an estimated US\$11,934 trillions (at 2001 raw commodity prices).

\section{ACKNOWLEDGEMENTS}

This work benefited from extensive assistance from Pauline Simpson and her staff at the National Oceanographic Library and Marine Information Advisory Centre, Southampton Oceanography Centre. I am particularly thankful to Peter Miles for his assistance in researching aspects of methane hydrates and for discussions about predicting these resources. I also thank Lindsay Parson for his assistance in identifying those offshore areas that have the potential to lie within nation states' extended legal continental shelf.

\section{REFERENCES}

AGTERBERG, F.P. \& FRANKLIN, J.M. 1987 - Estimation of the probability of occurrence of polymetallic massive sulfide deposits on the ocean floor. 467-483 in: P. Teleki et al (ed.) Marine Minerals.

ANON. - 1991 - NOAA \& MMS Marine Minerals CD-ROM Data Set, World Data Center for Marine Geology \& Geophysics, Boulder.

BATURIN, G.N. - 1998 - Mineralogy and mineral resources of the ocean floor. in, A.S.Marfunin (ed.) Advanced mineralogy, Vol 3: Mineral matter in space, mantle, ocean floor, biosphere, environmental management and jewellery, pp.204244, Berlin: Springer-Verlag. 437pp.

BATURIN, G.N. \& SAVENKO, V.S. - 1985 Mechanism of formation of phosphorite nodules, Oceanology, 25(6), 747-750.

BENTOR, Y.K. (ED.) - 1980 - Marine phosphorites - geochemistry occurrence, genesis, (A symposium held at Xth International Congress on Sedimentology in Jerusalem, Israel, 9-14 July, 1978). Tulsa, Okla: Society of Economic Paleontologists and Mineralogists, 249pp.

BINNS, R.A., SCOTT, S.D., BOGDANOV, Y.A.,
LISITZIN，A.P., GORDEEV，V.V., GURVICH, E.G., FINLAYSON, E.J., BOYD, T., DOTTER, L.E., WHELLER, G.E. \& MORAVYEV, V.G. - 1993 - Hydrothermal oxide and gold-rich sulfate deposits of Franklin Seamount, western Woodlark Basin, Papua New Guinea, Economic Geology, 88(8), 2122-2153.

BROADUS, J.M. - 1985 - Economic significance of marine polymetallic sulfides. In: Second international seminar on the offshore mineral resources: offshore prospecting and mining problems - current status and future developments. March 1984, Brest, France, 559-576.

BURNETT, W. C. \& RIGGS, S. R. (EDS.) - 1990

- Phosphate Deposits of the World, vol. 3, Neogene to Modern phosphorites, Cambridge University Press, Cambridge (pubs.).

BURNS, R. G. \& BURNS, V. M. - 1977 - Mineralogy, in: Glasby G. P. (ed.) Marine Manganese Deposits, Elsevier Oceanographic Series 15, Elsevier (pubs.) Amsterdam, 185-428.

CALVERT, S. E. - 1978 - Geochemistry of oceanic ferromanganese deposits, Phil. Trans. Royal Soc., London, A.290, 43-73.

CLARK, A., HUMPHREY, P., JOHNSON, C. J. \& PAK, D. K. - 1985 - Cobalt-rich manganese crust potential, US Dept. of the Interior, Mineral Management Servece, OCS Study MMS 85-0006, 35pp.

CLARK, A., JOHNSON, C. J. \& CHINN, P. A. - 1984 - Assessment of cobalt-rich manganese crusts in the Hawaiian, Johnson and Palymra Islands' exclusive economic zones, Natural Resources Forum, U.N., New York, 8/2, 163-174.

COLLETT, T.S. - 1992 - Potential of gas hydrates outlined, Oil \& Gas Journal, June 22, p. 84-87.

CRONAN, D. S. - 1977 - Deep-sea nodules: distribution and geochemistry, in: Glasby G. P. (ed.) Marine Manganese Deposits, Elsevier Oceanographic Series 15, Elsevier (pubs.) Amsterdam, 11-44.

CRONAN, D. S. - 1980 - Underwater minerals, Academic Press (pubs.), London, 121-195.

CRONAN, D. S. - 1983 - Criteria for the recognition of potentially economic manganese nodules and encrustaions in the $\mathrm{CCOP} / \mathrm{SOPAC}$ region 
of Central and Southwester Tropical Pacific. Technological Report No. 30, Economic and Social Commission for Asia and the pacific, U.N. Development Programme, 50pp.

CRONAN, D. S. - 1985 - A wealth of sea-floor minerals, New Scientist, June 6th, 34-38.

CRONAN, D. S. (ED.) - 2000 - Handbook of Marine Mineral Depoits, CRC press, (pub.), 347-368.

CRUIKSHANK, M.J. - 1992 - Marine mineral resources, in, W. A. Nierenberg (ed.) Encyclopedia of Earth system science, Vol.3, 113-123.

DIVINS, D.L., \& EAKINS, B. - in preparation. Total Sediment Thickness Map for the Southeast Pacific Ocean, edited by G.B. Udintsev, Intergovernmental Oceanographic Commission, International Geological-Geophysical Atlas of the Pacific Ocean.

DIVINS, D.L. \& RABINOWITZ, P.D. - 1991 Total sediment thickness map for the South Atlantic Ocean, in International Geological and Geophysical Atlas of the Atlantic and Pacific Oceans (GAPA), edited by G.B. Udintsev, 147148, Intergovernmental Oceanographic Comission.

DOBRYNIN, V.NM., KOROTAJEV, Y.P. \& PLYUSCHEV, D.V. - 1981 - Gas hydrates-a possible energy resource, in Meyer, R.F., and Olson, J.C., eds., Long-term energy resources: Pitman, Boston, 727-729.

EARNEY F. C. F. - 1990 - Marine Mineral Resources, Routledge (pubs.) London \& New York, $325 \mathrm{pp}$,

ELDERSFIELD, H. - 1977 - The form of manganese and iron in marine sediments, in: Glasby G. P. (ed.) Marine Manganese Deposits, Elsevier Oceanographic Series 15, Elsevier (pubs.) Amsterdam, 269-290.

EMERY, K. O. \& NOAKES, L. C. - 1968 - Economic placer deposits of the continental shelf, Committee for the coordination of joint prospects for mineral resources in Asian Areas, Techn. Bull., 1,95 .

FRAZER, J. Z. - 1977 - Mangenese nodule reserves; an updated estimate, Marine Mining, 1/ $1 \& 2,103-123$.

FRAZER, J.Z. \& FISK, M. B. - 1980 - Geologic factors related to characterisation of seafloor manganese nodules deposits, Report for the U.S. Dept. of the Interior, Bureau of Mines, Scripps Institute of Oceanography Reference 79-19, $41 \mathrm{pp}$.

FRAZER, J. Z. \& WILSON, L.L. - 1977 - Manganese nodule resources in the Indian Ocean, Marine Mining, 2,/3, 257-292.

GLASBY, G.P. - 1977 - Marine manganese deposits, Elsevier Oceanography Series, 15, 1-11, Elsevier (pubs.) Amsterdam.

GORNITZ, V. \& FUNG, I. - 1994 - Potential distribution of methane hydrates in the world's oceans: Global Biogeochemical Cycles, v. 8, no. 3, 335-347.

GREENSLATE，J., FRAZER，J.Z. \& ARRHENIUS, G. - 1973 - Origin and deposition of selected transition elements in the seabed, in: Morgenstein M. (ed.) Papers on the Origin and Distribution of Manganese Nodules in the Pacific and Prospects for Exploration, Hawaii Institute of Geophysics, 45-70.

GROSS, G. A. \& MCLEOD, C. R. - 1987 Metallic Minerals on the Deep Seabed, Geological Survey of Canada, 86/21, 65p.

HALBACH, P., 1983. The polymetallic deposits of the deep-sea bottom within the Pacific Ocean, Monograph Series on Mineral Deposits, 22, Gebruder Borntraeger (pubs.) Berlin-Stuttgart, 109-123.

HALBACH P. \& MANHEIM F. T. - 1984 - Potential of cobalt and other metals in ferromanganese crusts on seamounts of the Central Pacific Basin, Marine Mining, 4, 319-336.

HALBACH P., SATTLER C. D., TEICHMASNN F. \& WAHSNER M. - 1989

- Cobalt-rich and platinum bearing manganese deposits on seamounts: nature, formation and metal potential, Marine Mining, 8, 23-36.

HANNINGTON, M.D. \& SCOTT, S.D. - 1988 - Gold and silver potential of polymetallic sulfide deposits on the sea floor, Marine Mining, 7(3), 271-285.

HARBEN, P. W. \& BATES, R. L. - 1990 - Industrial Minerals - Geology and world deposits, Industrial Minerals Div., Metal Bull., London(pub.).

HAYES, D.E. \& LA BRECQUE, J.L. - 1991 - 
Sediment Isopachs: Circum-Antarctic to 30S, in Marine Geological and Geophysical Atlas of the Circum-Antarctic to 30S, edited by D.E. Hayes, 29-33, American Geophys. Union, Washington, D.C.,.

HAYES, B. W., LAW, S. L., BARRON, D. C., KRAMER, G. W., MAEDA, R. \& MAGYAR M. J. - 1985 - Pacific manganese deposits: characterisation and processing, U.S. Dept. of the Interior, Bureau of Mines, Bulletin 697, 44pp.

HEIN, J. R. \& MORGAN, C. L - 1999 - Influence of substrate rocks on Fe-Mn crust compositions, Deep-Sea Research I, 46, 855-875.

HEIN, J. R., KOSCHINSKY, A., HALBACH, P., MANHEIM, F. T., BAU M., KANG, JK. \& LUBICK, N. - 1997 - Iron and manganese oxide mineralisation in the Pacific, in: Hein et al., (eds.) Manganese Mineralisation: Geochemistry and Mineralogy of Terrestrial and Marine Deposits, Geol. Soc. Special Publication 119, 123-138.

HERZIG, P.M. - 1999 - Economic potential of seafloor massive sulphide deposits: ancient and modern. Philosophical Transactions of the Royal Society of London A 357(1753) 861-875.

HERZIG, P.M. \& HANNINGTON, M.D. - 1995 - Polymetallic massive sulfides at the modern seafloor: a review. Ore Geology Reviews, 10, 95115.

HERZIG, P. M. \& HANNINGTON, M. D. 2000 - Plymetallic sulphides and gold mineralisation, in Cronan D. S. (ed) Handbook of Marine Mineral Depoits, CRC press, (pub.), London, 347-368.

HERZIG, P.M., HANNINGTON, M.D., FOUQUET, Y., VON STACKELBERG, U. \& PETERSEN, S. - 1993 - Gold-rich polymetallic sulfides from the Lau Back Arc and implications for the geochemistry of gold in seafloor hydrothermal systems of the southwest $\mathrm{Pa}$ cific. Economic Geology, 88(8), 2182-2209.

HOLSER, W. T. - 1979 - Mineralogy of Evaporites, in: Burns, R. G. (ed.) Marine Minerals, Reviews in Mineralogy, 6-21.

HOLSER, W. T., CLEMENT, G. P., JANSA \& L. F. WADE, J. A. - 1988 - Evaporite deposits of the North Atlantic rift, In: W. Manspeizer (ed.), Triassic-Jurassic rifting, Part B, 525-556.

INTERNATIONAL ENERGY AGENCY - 1996

- Global Offshore Oil Prospects to 2000. IEA report, 120pp.

JONES, H. A. \& DAVIES, P. J. - 1979 - Preliminary studies of offshore placer deposits, Mar. Geol., 30, 243.

JURY, A. P. \& HANCOCK, P. M. - 1989 - Alluvial gold deposits and mining prospects on the West coast, South Island, New Zealand, in: Mineral deposits of New Zealand, Kear D. (ed.), Austral. Inst. Mining metallurgy, Victoria, 147pp.

KENT, P. - 1980 - Minerals from the Marine Environment, Edward Arnold (pubs.).

KESLER, S. E. - 1994 - Mineral Resources, Economics and the Environment, MacMillan College Publishing Co., (New York), 142pp.

KLETT, T. R., AHLBRANDT, T. S., SCHMOKER, J. W. \& DOLTON, G. L. 1999 - Ranking of the world's oil and gas provinces by known petroleum volumes, U. S. Department of the Interior, U.S. Geological Survey , Open-File Report 97-463

KOMER, P. D. \& WANG, C. - 1984 - Processes of selective grain transport and the formation of beach placer deposits, Jour. Geol., 92, 637-648

KU, T. L. - 1977 - Rates of accretion, in: Glasby G. P. (ed.) Marine Manganese Deposits, Elsevier Oceanographic Series 15, Elsevier (pubs.) Amsterdam, 249-268.

KUDRASS, H. R. - 1987 - Sedimentary models to estimate the heavy mineral potential of shelf deposits, in: Marine Minerals, Teleki, P. G., Dobson M. R., Moore J. R. and von Stackelberg U., (eds.), Reidel Publishing, Dordrecht, 39p.

KUDRASS, H. R. - 2000 - Marine placer deposits and sealevel changes, in Cronan D. S. (ed) Handbook of Marine Mineral Depoits, CRC press, (pubs.), 3-12.

KVENVOLDEN, K.A. - 1988 - Methane hydratea major reservoir of carbon in the shallow geosphere?: Chemical Geology, v. 71, 51-51.

KVENVOLDEN, K.A. - 1993 - Gas hydrates as a potential energy resource - a review of their methane content, in Howerll, D.G., ed., The future of energy gases: U.S. Geological Survey 
Professional Paper 1570, 555-561.

KVENVOLDEN, K.A., GINSBURG, G.D. \& SOLOVIEV, V.A. - 1993 - Worldwide distribution of subaquatic gas hydrates, Geo-Marine Letters, 13(1), 32-40.

LEE, M. W., HUTCHINSON, D. R., AGENA, W. F., DILLON, W. P., MILLER, J. J. \& SWIFT, B. A. - 1994 - Seismic character of gas hydrates on the southeastern U.S. continental margin, Marine Geophys. Res., 16, 163-184.

LI, Y. - 1995 - Ttansfer of technology for deep seabed mining: the 1982 Law of the Sea Convention and beyond, in Publication on Ocean Development, A series of studies on the International, Legal, Institutional and Policy Aspects of Ocean Development, Oda S. (ed.).

LUDWIG, W.J., \& HOUTZ, R.E. - 1979 Isopach Map of the Sediments in the Pacific Ocean Basin, colour map with text, Am. Assoc. Pet. Geol., Tulsa.

MACDONALD, G.J. - 1990 - The future of methane as an energy resource: Annual Review of Energy, v. 15, 53-83.

MANHEIM, F. T - 1972 - Composition and origin of manganese-iron nodules and pavements on the Blake Plateau, in: Horn D. R. (ed.) Papers from a conference on Ferromanganese Deposits on the Ocean Floor, The Office for the International Decade of Ocean Exploration, National Science Foundation, Washington, D. C., 105pp.

MANHEIM, F. T. - 1979 - Marine Phosphorites, in: Burns, R. G. (ed.) Marine Minerals, Reviews in Mineraolgoy, 6-15.

MANHEIM, F. T. - 1986 - Marine cobalt resources, Science, 232, 600-608.

MATHHIAS, P.K., RABINOWITZ, P.D., \& DIPIAZZA, N. - 1988 - Sediment Thickness map of the Indian Ocean, Map 505, Am. Assoc. Pet. Geol., Tulsa..

MAX, M.D. - 1990 - Gas hydrate and acoustically laminated sediments: potential environment cause of anomalously low acoustic bottom loss in deep -ocean sediments, U.S. Naval Research Laboratory, NRL Report 9235, 68pp.

MCIVER, R.D. - 1981 - Gas hydrates, in Meyer, R.F., and Olson, J.C., (eds.), Long-term Energy Resources: Pitman, (pubs.) Boston, 713-726.
MCKELVEY, V. E. - 1968 - Mineral potential for the submerged parts of the continents, in Mineral resources of the word ocean: U.S. Geol. Survey, University of Rhode Island, U.S. Navy, Occasional Publication 4, 31-38.

MCKELVEY, V.E.\& WANG, F.H. - 1969 - World subsea mineral resources, in: A discussion to accompany miscellaneous geologic investigations map 1-632, U.S. Geol. Survey, Dep. U.S. of the Interior.

MERO, J. L. - 1965 - The Mineral Resources of the Sea, Elsevier (pubs.) Amsterdam, 312 pp.

MERO, J. L. - 1977 - Economic aspects of nodule mining, Glasby G. P. (ed.) Marine Manganese Deposits, Elsevier Oceanographic Series 15, Elsevier (pubs.) Amsterdam, 327-356.

MEYER, R.F. - 1981 - Speculations on oil and gas resources in small fields and unconventional deposits, in: Meyer, R.F., and Olson, J.C., (eds.), Long-term Energy Resources: Pitman (pubs.), Boston, 49-72.

MILES, P. R. - 1995 - Potential distribution of methane hydrate beneath the European continental margins, Geophysical Research Let., 22/23, 3179-3182.

MITCHELL, M. \& GARSON, JR. - 1981 - Mineral deposits and global tectonic settings, Academic Press, New York.

MORGAN, C. L. - 2000 - Resource estimates of the Clairion-Clipperton manganese nodule deposits, in: Cronan D. S. (ed.) Handbook of Marine Mineral Depoits, CRC press, (pub.), 145170.

MOSS, R., SCOTT, S.D. \& BINNS, R.A. - 1997 - Concentrations of gold and other ore metals in volcanics hosting the PACMANUS seafloor sulfide deposit. JAMSTEC Journal of Deep Sea Research, No.13, 257-267.

MÜLLER, R.D., ROEST, W.R., ROYER, J.-Y., GAHAGAN, L.M., \& SCLATER - 1997 J.G., Digital isochrons of the world's ocean floor, Journal of Geophysical Research, 102, 32113214.

MURRAY, J. - 1878 - On the distributionof volcanic debris over the seafloor of the oceans, its character, source and some of the products of its disintegration and decomposition, Proceedings 
Royal Society of Edinburgh, 9, 247-261.

MURRAY, J. \& IRVINE, R. - 1895 - On the manganese oxide and manganese nodules in marine deposits, Transactions of the Royal Society of Edinburgh, 37, 721-742.

MURRAY, J. \& RENARD, A. F. - 1891 - Report on the deep sea deposits, in: Thompson C. W. (ed.) Report of the voyage of the HMS Challeneger, Eyre \& Spotiswood (pubs.) London, 525pp.

PEARSON, J. S. - 1975 - Ocean Floor Mining, Noyes Data Corp. (pubs.), New York and London.

PERYT, T.M. (ED.) - 1987 - Evaporite basins, Berlin: Springer-Verlag. 188pp.

PRESCOTT, J. R. V. - 1985 - The maritime political boundaries of the world, Methun \& Co, London (pub.),

RAO, P.S. \& NAIR, R.R. - 1991 - Mineral resources of the seabed in, First International seminar and exhibition on Exploration Geophysics in Nineteen Nineties, extended abstracts. Volume II, 476-483.

RAWSON, M. D. \& RYAN, W. B. - 1978 - Ocean floor sediments and polymetallic nodules, Sheet 1, Lamont-Doherty Geological Observatory, miscellaneous map sheet.

RONA, P. A. - 1969 - Possible salt domes in the deep Atlantic off north-west Africa, nature, 224/ $5215,141-143$.

RONA, P. A. - 1988 - Hydrothermal mineralisation at oceanic ridges, Can. Min. 26, 431-445.

RONA, P.A. \& KOSKI, R. - 1985 - Introduction to theme issue on marine polymetallic sulfides.
Marine Mining, 5(2), 101-102.

SCHNEIDER, E. D. - 1969 - The deep-sea - a habitat for petroleum?: Undersea Technology, Oct. 1969, 32-34.

SCOTT, S.D. - 1985 - Seafloor polymetallic sulfide deposits: modern and ancient. Marine Mining, 5(2), 191-212.

SCOTT, S.D. \& BINNS, R.A. - 1995 - Hydrothermal processes and contrasting styles of mineralization in the western Woodlark and eastern Manus basins of the western Pacific. 191-205 in, Hydrothermal vents and processes, L.M.Parson, C.L.Walker \& D.R.Dixon (eds.). London: Geological Society. 411pp.

SHILO, N. A. - 1970 - Placer-forming minerals and placer deposits, Pacific Geol., 2-29.

SMITH, W. H. F. \& WESSEL, P. - 1990 Gridding with continuous curvature splines in tension. Geophysics, 55, 293-305,

TELEKI, P. G. - 1987 - Dobson M. R., Moore J. R. and von Stackelberg U., (eds.), Marine Minerals, Reidel Publishing, Dordrecht, 39pp.

WARREN, J. - 1999 - Evaporites: their evolution and economics, Blackwell Science (pubs.) Oxford.

YIM, W. W-S. - 1991 - Tin placer genesis in northern Tasmania, in: the Cainozoic in Australia: A reappraisal of the evidence, Williams et al., (eds.) Spec. Pub. 18, Geol. Soc. Australia, Sydney, 232.

YIM, W. W-S. - 2000 - Tin placer deposits on continental shelves, in Cronan D. S. (ed) Handbook of Marine Mineral Depoits, CRC press, (pubs.), London, 27-66.

\section{NOTE ABOUT THE AUTHOR}

\section{BRAMLEY J.MURTON}

Received his BSc (Hons) in Geology from the University of Edinburgh in 1982. He concluded his $\mathrm{PhD}$ in Geology from Open University in 1986. He was Royal Society visiting research fellow at the Cyprus Geological Survey in 1987 and research fellow at Open University and University of Durham in 1988 and 1989, respectively. From 1990 to 1995 he jointed the marine geology and geophysics group at the IOSDL. In
September 1995, he moved to the Southampton Oceanographic Centre (Challenger Division for Seafloor Processes). Since 1996 he has been working as scientist at the Crustal Processes Group, CDSP. His main area of interest are the following: structure, composition and evolution of oceanic lithosphere and mantle; submarine volcanic systems, eruption processes and their global impacts; deep-ocean exploration - exploration technology and sonar interpretation. 